\title{
Structural Relations between Physical and Mental Health Based on Flourishing Mediated by Optimism in Nursing Students
}

\author{
Elham Yavari Barhaghtalab ${ }^{1}$, Mohammadreza Seirafi ${ }^{2}$, Maryam Kalhornia Golkar ${ }^{3}$
}

\begin{abstract}
Background \& Aims: Recently, special attention has been paid to physical and mental health and its predictors among the researchers of psychology. Health is a multidimensional concept, and its dimensions affect each other and the health of the individual and community. Health is essential to the fulfillment of social roles, and humans should be fully active if they feel healthy and are considered healthy by the society. The nursing profession plays a pivotal role in the provision of healthcare services in every country. Therefore, the physical and mental health of nurses and improving their professional performance in patient care are of utmost importance. Identifying and determining the influential factors in the physical and mental health of nurses is crucial in this regard. The present study aimed to provide a model of prosperity and optimism to better understand the physical and mental health of nursing students. The importance of the research subject is that health is not only defined as the absence of diseases and encompasses physical, mental, and social welfare as well. However, this comprehensive definition is rather ideal and unattainable, and it may not be easy to distinguish between health and disease as such. By this definition, health should be considered a high peak that can never be conquered, while everyone must strive to achieve it. Researchers believe that health and disease are not an absolute and independent state, but rather a process in which the influence of cultural, social, and psychological factors is highlighted in the development of the disease. Considering the valuable role of positivity, studies on the influential factors in mental and physical health are of particular importance. In this regard, the variables of prosperity, positive emotions, and optimism have been shown to affect physical and mental health. The present study aimed to provide a model for the assessment of physical and mental health using flourishing mediated by positive emotions and optimism.
\end{abstract}

Materials \& Methods: This analytical-correlational study was conducted on the nursing students of Hazrat Fatemeh School of Nursing and Midwifery in Shiraz, Iran in 2019, including 300 subjects (243 females and 57 males). The participants were selected via stratified random sampling and using a questionnaire. Data were collected using SF-36, HFQ, and revised life orientation test (LOT-R). Data analysis was performed in SPSS version 16 and AMOS version 22 software.

Results: The findings showed that the flourishing subscales of positive emotions, relationships, and optimism directly affected the physical and mental health of the students. In addition, the variables of positive emotions and relationships in the final model directly and indirectly caused changes in physical health through the variable of optimism, and the subscale of progress in the final model only had an indirect impact through the variable of optimism. On the other hand, the subscale of meaning had no effect on the physical or mental health of the students.

Conclusion: With regard to the correlation of optimism and physical/mental health, our findings indicated individuals with high optimism are often active, creative, and hardworking, while they are also good initiators and planners. Furthermore, these individuals are able to make the best of stressful situations, which in turn

\footnotetext{
1. Department of Health Psychology, Islamic Azad University, Kish International Branch, Kish Island, Iran ${ }^{2}$. Department of Psychology, Islamic Azad University, Karaj Branch, Alborz, Iran（Corresponding author) Tel: $09125072551 \quad$ Email: mohamadreza.seirafi@kiau.ac.ir

3. Department of Psychology, Islamic Azad University, Karaj Branch, Alborz, Iran
} 
makes them less exposed to the further risks and pressure caused by stressful events. The immune system performs better in the individuals with high optimism, and they have better coping abilities against stress by using more effective coping strategies, such as reassessment and problem-solving. Therefore, it is expected that training on flourishing and increasing optimism through positive psychology techniques could be an effective mechanism to correct false beliefs and prevent psychosomatic and psychological disorders in nursing students. Furthermore, the effects of such training interventions could be intensified with the incorporation of interventional programs in the field of student empowerment against stress.

Keywords: Health, Flourishing, Optimism, Positive Psychology, Nursing Student

\section{Conflict of Interest: No}

How to Cite: Yavari Barhaghtalab E, Seirafi M, Kalhornia Golkar M. Structural Relations between Physical and Mental Health Based on Flourishing Mediated by Optimism in Nursing Students. Iran Journal of Nursing. 2020; 33(126):28-43.

Received: 8 Jul 2020

Accepted: 7 Oct 2020 


\title{
روابط ساختارى بين سلامت جسمى - روانى بر اساس شكوفايى با ميانجى كرى خوشبينى در دانشجويان برستارى
}

\author{
الهبام ياورى برحقطلب'، محمدر ضا صيرفى '، مريم كلهرنيا كَل كارّّ.
}

\begin{abstract}
جكSי
زمينه و هدف: شغل برستارى در ارائهى خدمات مراقبت بهداشتى در همهى كشورها داراى نقش محورى بوده و بنابراين سلامت جسمى - روانى

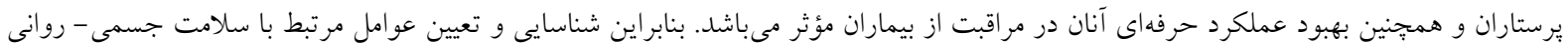

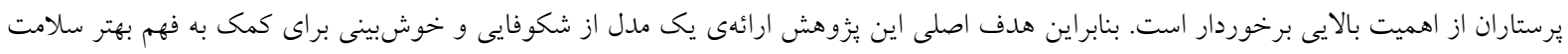
جسمى - روانى دانشجويان برستارى بود.

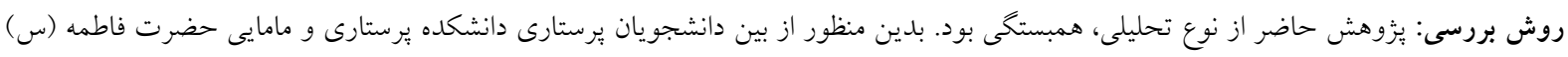

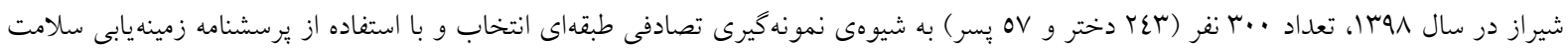

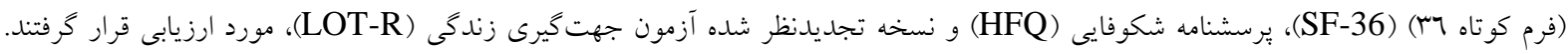

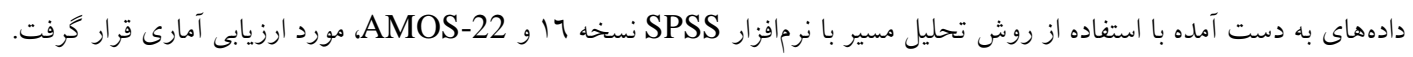

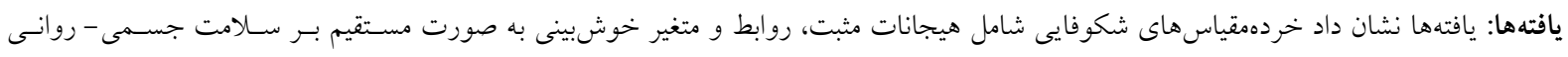

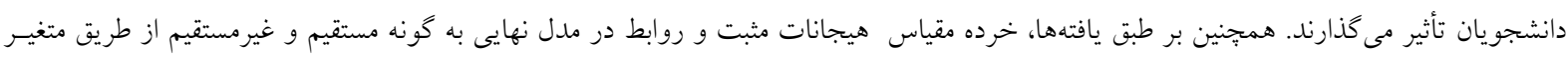

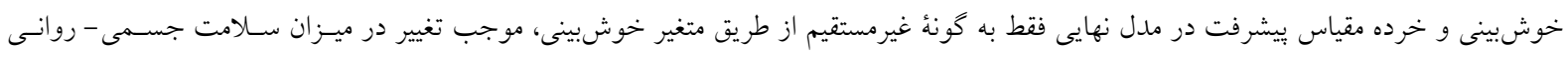

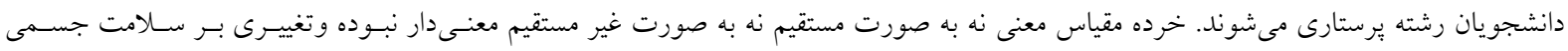

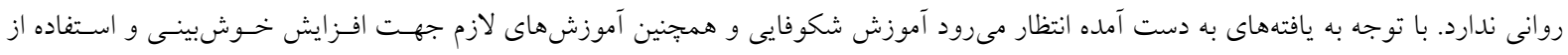

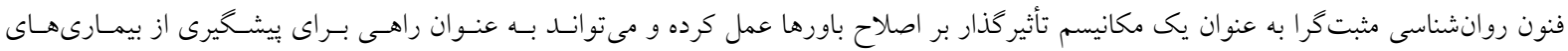

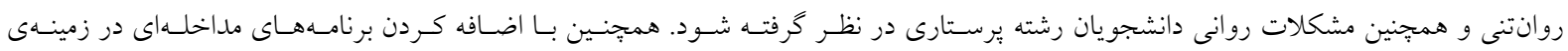

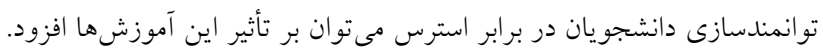

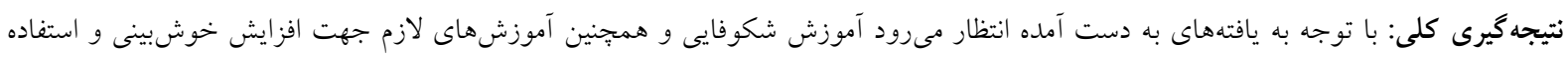

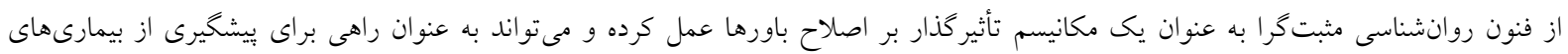

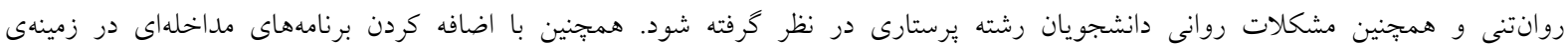

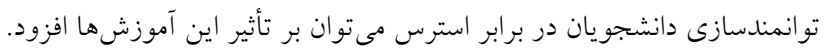

كليد وازهها: سلامت، شكوفايى، خوشبينى، روانشناسى مثبت، دانشجوى برستارى. تعارض منافع: ندارد

تاريخ دريافت: 99/L/11 (4) تاريخ بذيرش: 99/N/17

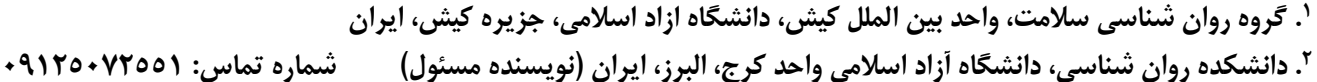
Email: mohamadreza.seirafi@ $@$ kiau.ac.ir

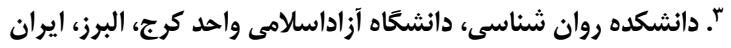


هيجانهاى مثبت (positive emotion)، تعهد و و

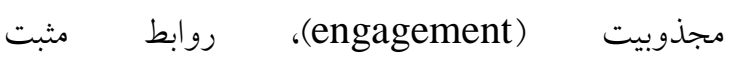

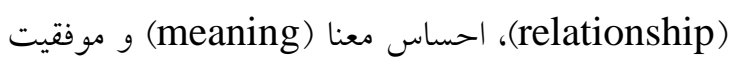
و بيشرفت (achievement) است، در كنار هم قرار داده و نظريه بهزيستى جامع را ارائه نموده است. افراد با بال

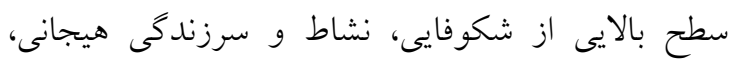

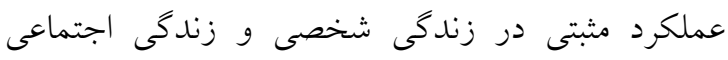

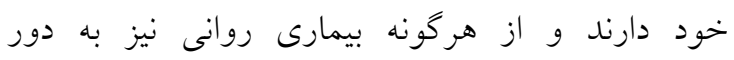

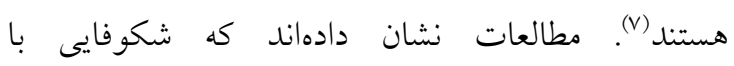

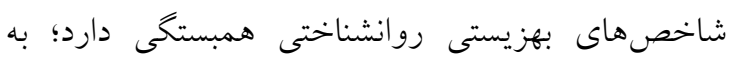

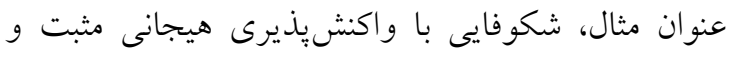

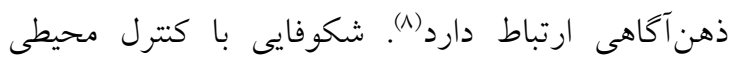

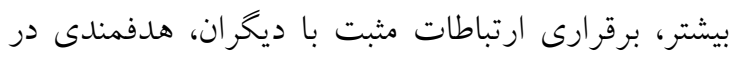
زندكى و رشد شخصى نيز ارتباط دارد(9)، و اميد به به بهرئ

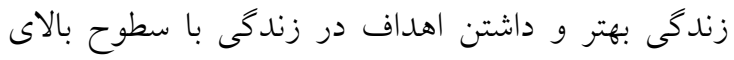

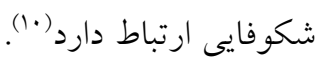
يكى از متغيرهايى كه به نظر مىرسد از شكوفايى تأثير

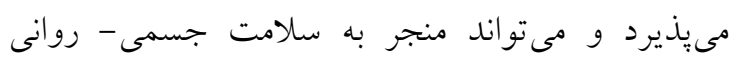

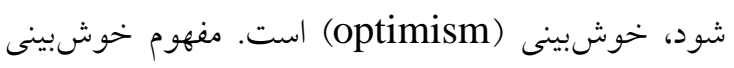
يكى از مفاهيمى است كه در حوزه روانشناسى مثبت مطرح است. در واقع خوشبينى به جهت كزينى الشئى الشاره

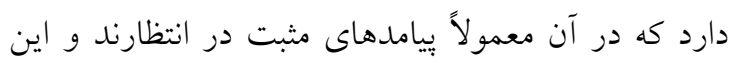

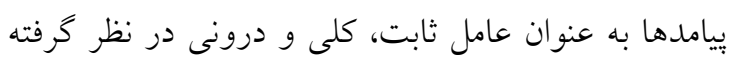
مىشوند (1'). خوش بينى به عنوان كرايش كلى نس نسبتاً بايدار

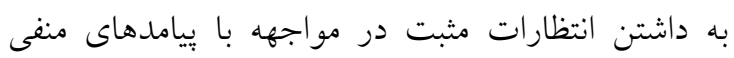

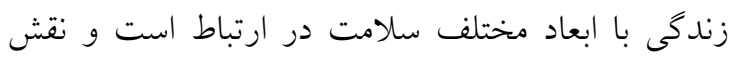
مهمى در يِيشيرى از بروز اختلالات جسمى و بـ روانى

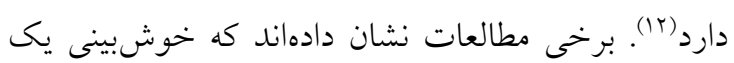

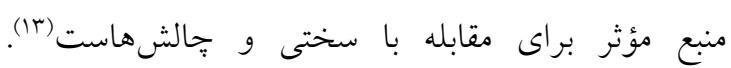

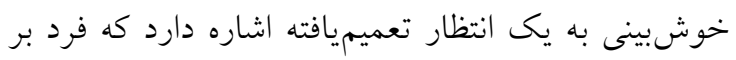

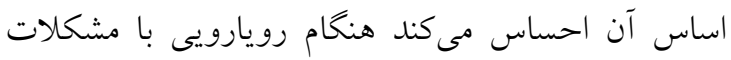

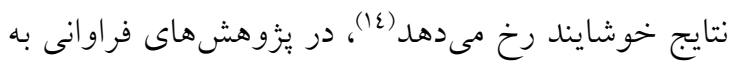
عنوان متغير واسطهاى با سازههاى روانشناختى از قبول

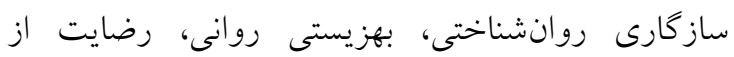

\section{مقدمه} شغل يرستارى در ارائهى خدمات مراقبت بهداشتى در همهى كشورها داراى نقش محورى بوده و بنابراين

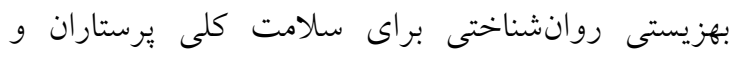

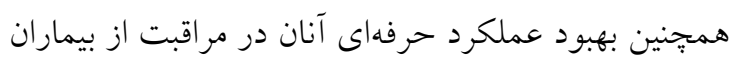

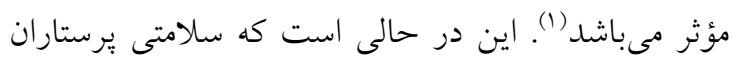

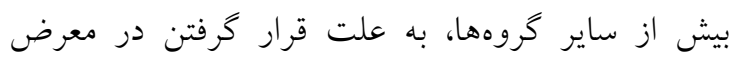

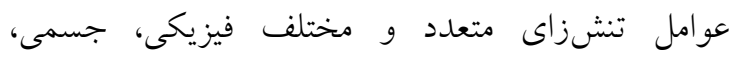

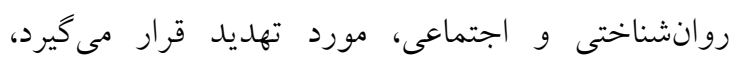
سلامتى يكى مفهوم جندبعدى است و اين ابعاد بر يكديخر

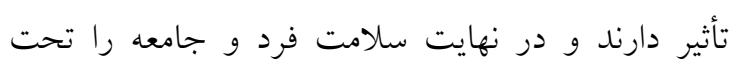

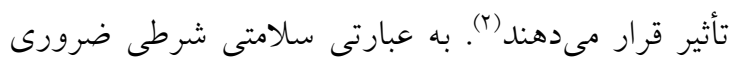
براى ايفاى نقشهاى اجتماعى است و همه انسانها در

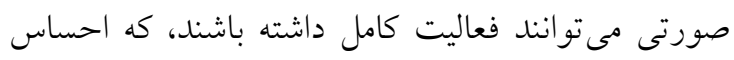
كنند سالماند و جامعه هم آنها را سالم بداند (r). در مورد

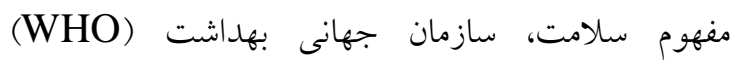
بذيرفتهترين (World Health Organization) تعريف را ارائه داده است: (اسلامتى حالت رفاه و آسايش بلإن

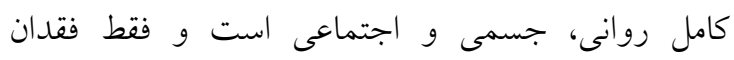

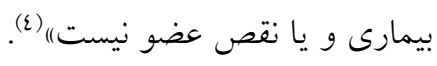

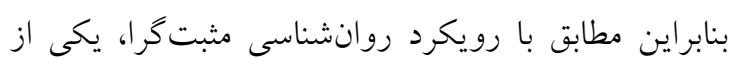

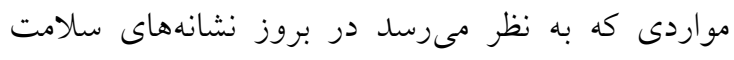

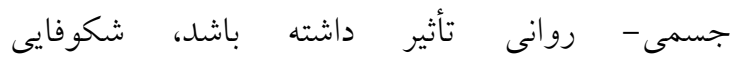
(flourishing)

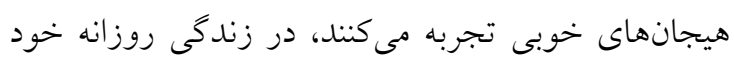

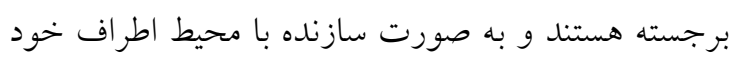

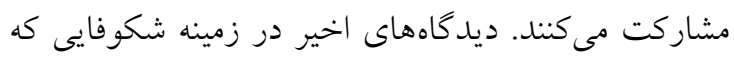
از نظريههاى شادكامى يا احساس رضايت از زندكى (0) به كنه

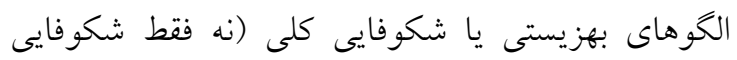

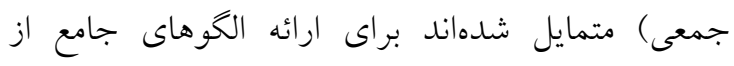
عملكرد بهينه فرد، هم بر نياز روانشناختى رضايت و هم بمائ

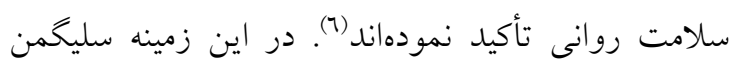

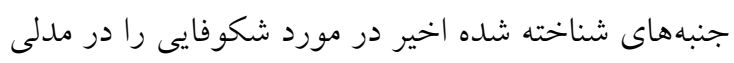

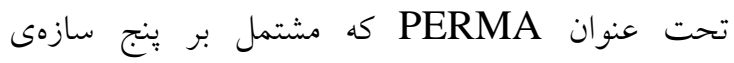


شده است (17). بنابراين بررسى عوامل مرتبط با سلامت

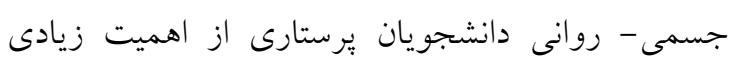

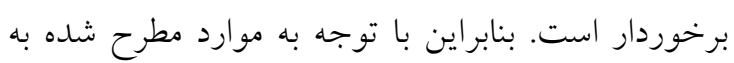

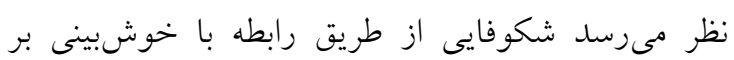

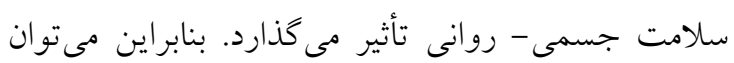

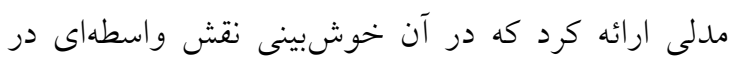
رابطه بين شكوفايى و سلامت جسمى - روانى ايفا مى كند.

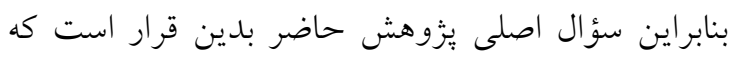

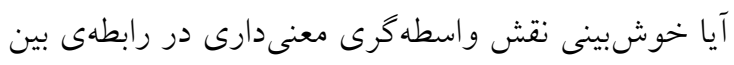

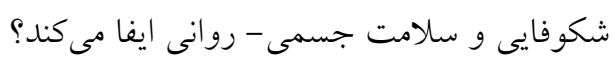

\section{روش بررسى}

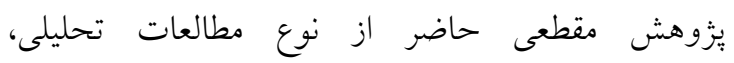
همبستكى بود كه جامعلى آن شامل تمامى دانشجويان

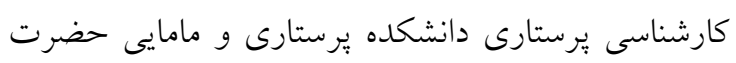
فاطمه (س) شيراز در سال تحصيلى

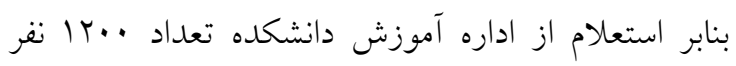
19 aV•) درصد) بودند. ملاكهاى ورود به مطالعه عبارت بود از:

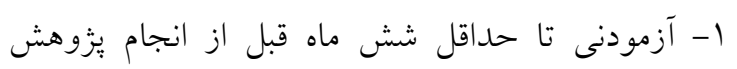

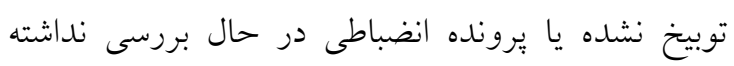

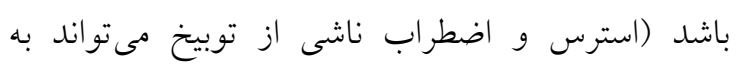

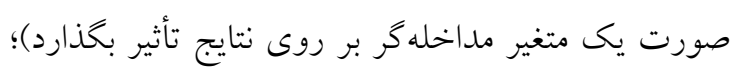

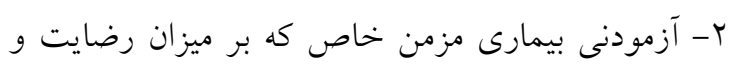

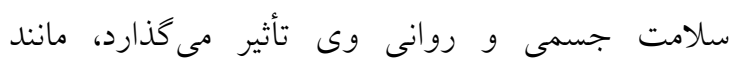

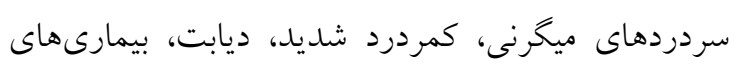

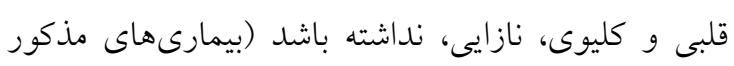

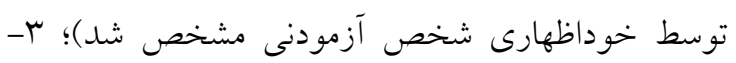

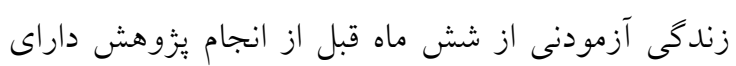

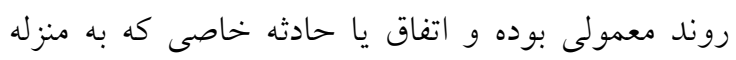

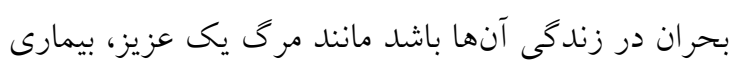

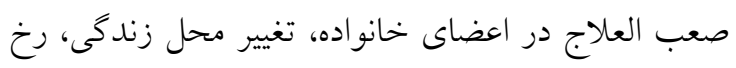
نداده باشد؛ ملاكهاى خروج از مطالعه عبارت بود ازي:

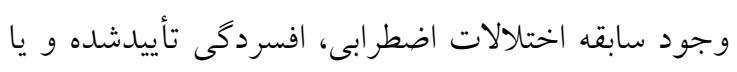

زندكى و در ارتباط بوده است، بيماران داراى سطح بايين

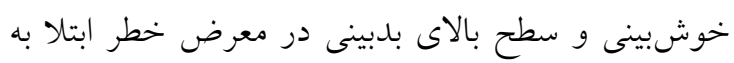

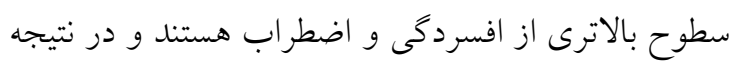
با كيفيت زندكى بايين روبرو مى شوند (10).

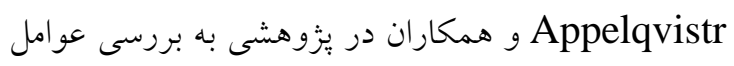

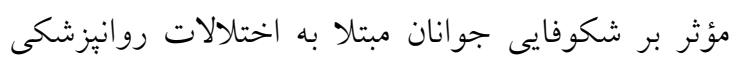

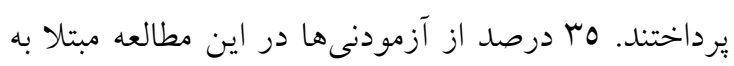
اختلال خلقى، اضطراب يا اختلال استرس بودند. يافتهها

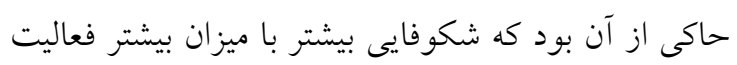

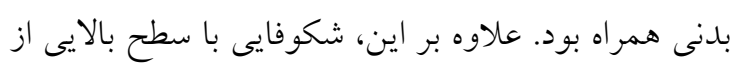

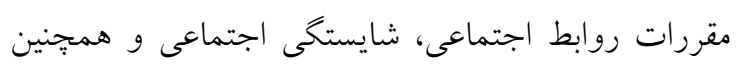
قابليت عملكرد عمومى همراه بود. Rasmussen HN Scheier MF, Greenhouse دادند كه خوشبينى بيشبينى كنندهى سلامت جسمى بيماران است به طورى كه خوشبينى در تحول بيمارى و

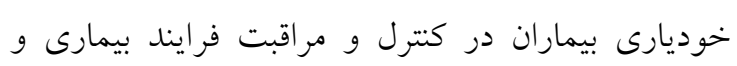
افزايش سلامت جسمى كمى زيادى مى كند. Fournier

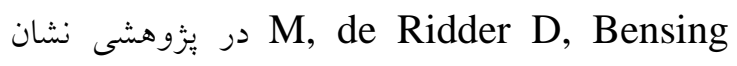
دادند كه كاهش خوشبينى و افزايش رنج و ناراحتى در

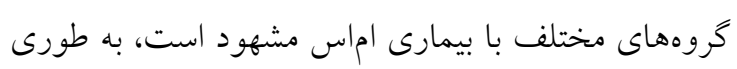

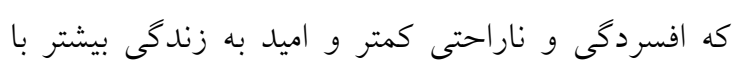

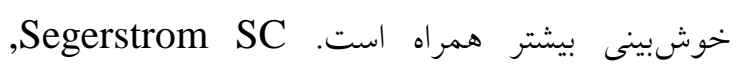
Taylor SEKemeny

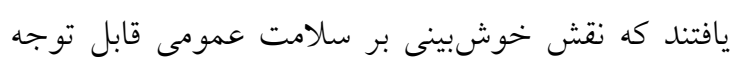

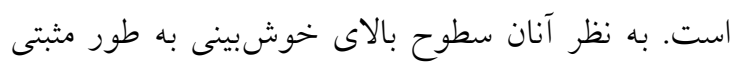

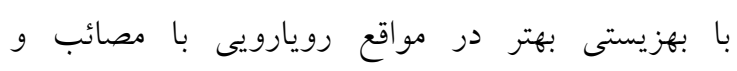

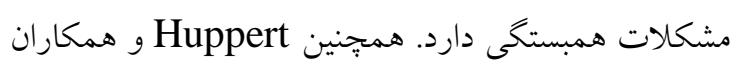
در يززوهشى نشان دادند كه خوشبينى رابطه معنى دارى همجئين با سلامت جسمى - روانى دارد. باقيانى مقدم و همكاران

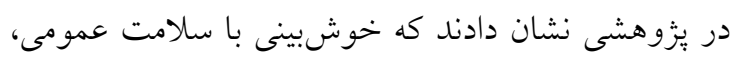

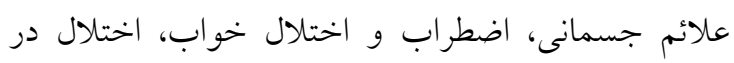
كاركرد اجتماعى و افسردكى همبستخى قوى داشت إنى

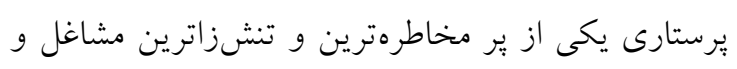

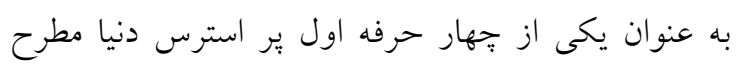


مجذوبيت) ساخته شده است و در آن آزمودنى بايد ميزان

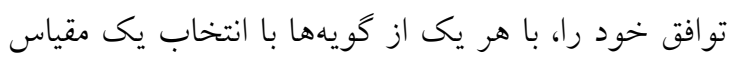

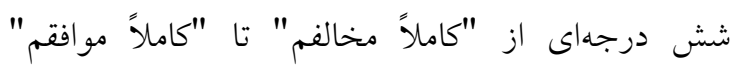

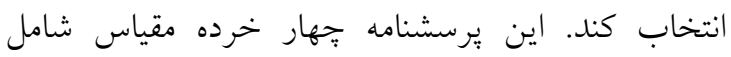

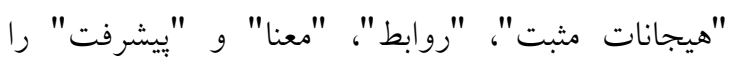

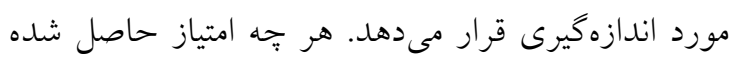

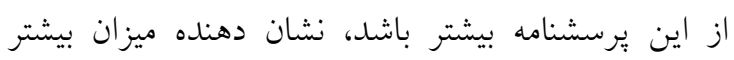

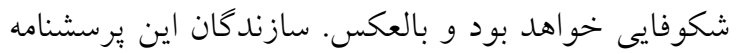
ضمن گزارش روايى صورى، محتوايى و سازهاى (ع عامل

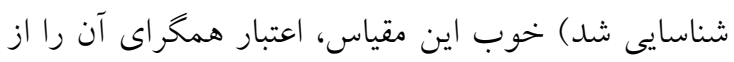

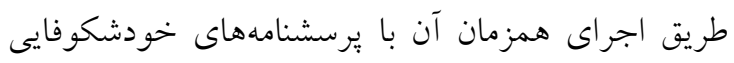

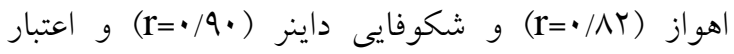

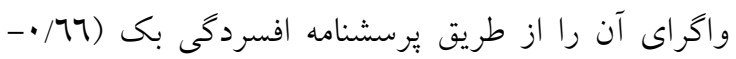
بررسى و مورد تاييد قرار دادند. سليمانى و همكاران (r=

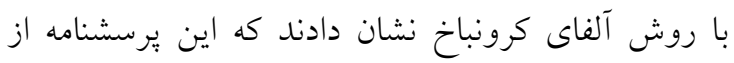

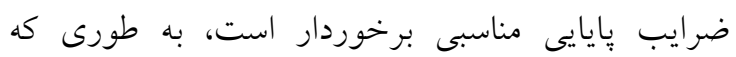

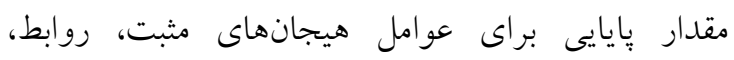

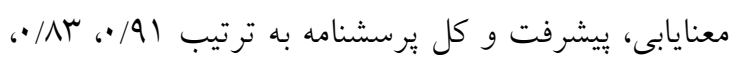

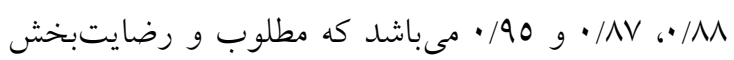

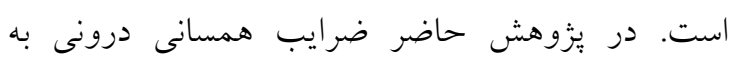
روش آلفاى كرونباخ براى خردهمقياسهاى هيجانات

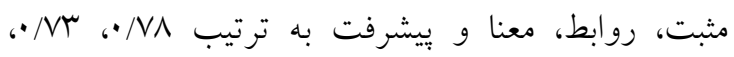

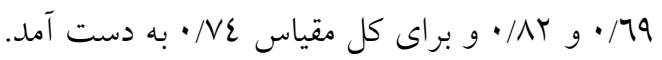

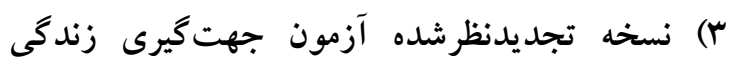
(revised life orientation test) (LOT-R) اين ترسشنامه توسط Scheier و همكاران و براى افراد

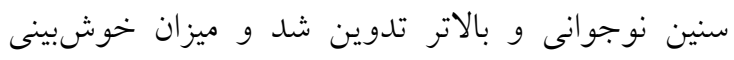

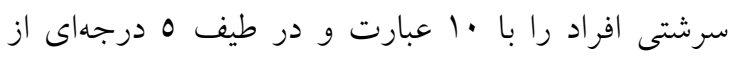

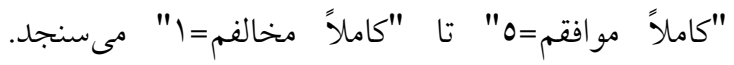

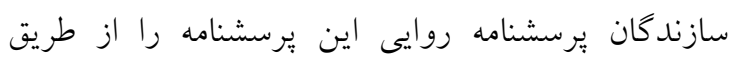

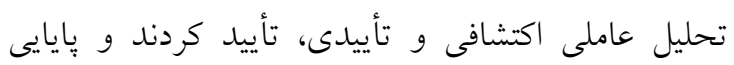

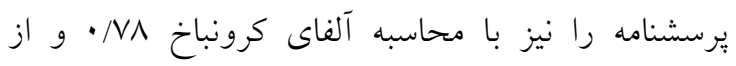

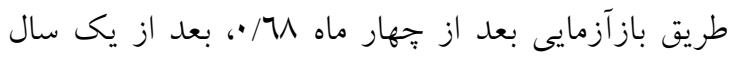

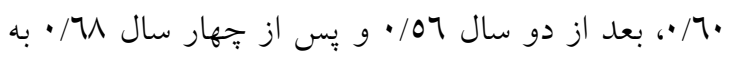

مصرف داروهاى مؤثر بر روان. حجم نمونه مورد بررسى

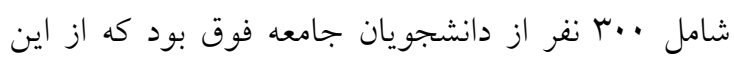

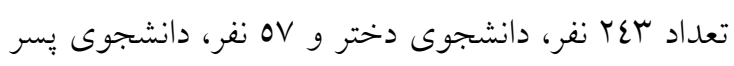
بودند كه به ترتيب اله درصد و 19 درصد از حجم نمون نمونه مىباشند. Wolf و همكاران با روش شبيهسازى مونت كارلو (Monte Carlo simulation) نشان دادند كه

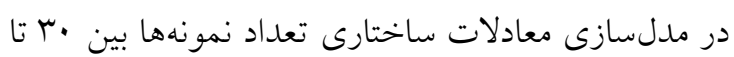
.

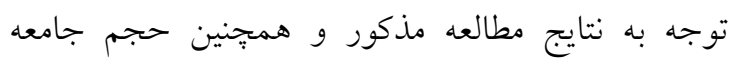

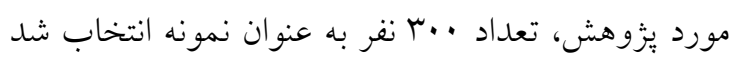

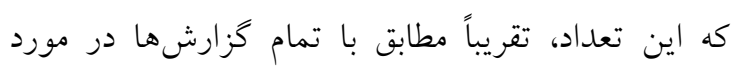

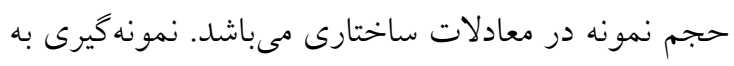

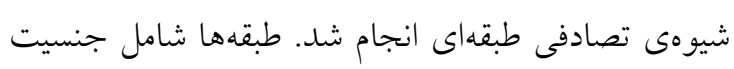
دانشجويان بود و با توجه به درصد فراوانى دانشجويان

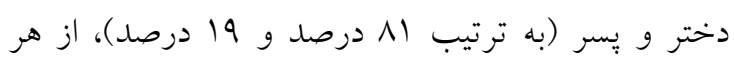
طبقه به تناسب حجم هر طبقه، حجم نمونه در آن طبقه

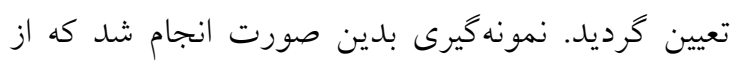

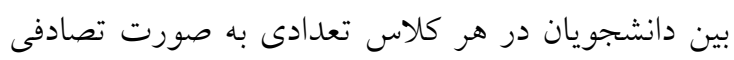

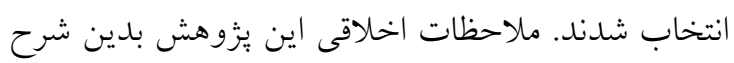

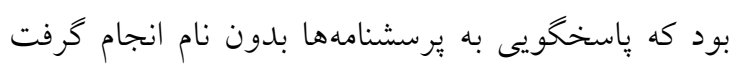

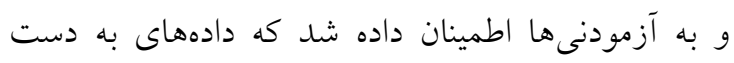

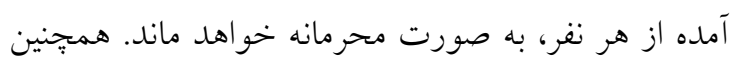
به آزمودنىها كوشزد شد كه شركت در ئزوهش به كاملاً

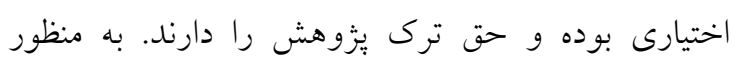

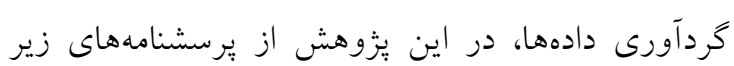
استفاده شد: () برسشنامه جمعيت شناختى: در ابتداى برسش نامه از

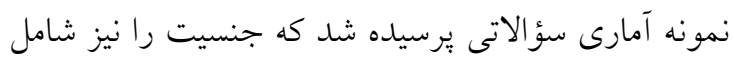
مىشود ويرسش نامه جمعيت شناختى را تشكيل داده

human flourishing (r برسشنامه شكوفايى (T) (questionnaire (HFQ)

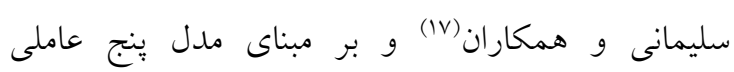

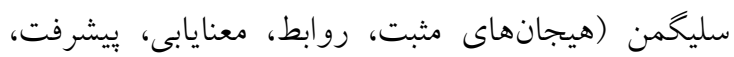


به منظور توصيف، تجزيه و تحليل دادهاى آمارى در اين

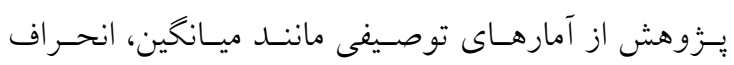

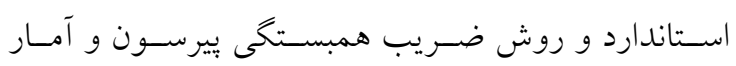

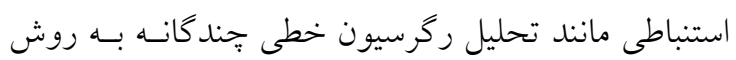

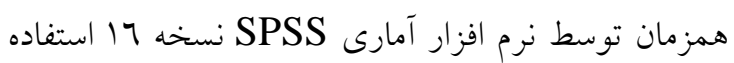

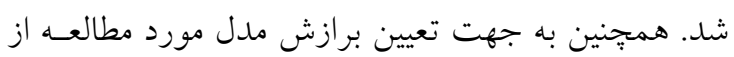

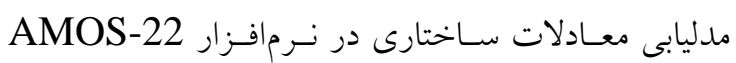

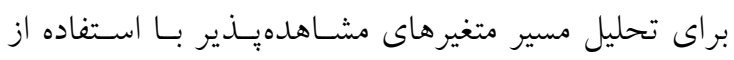

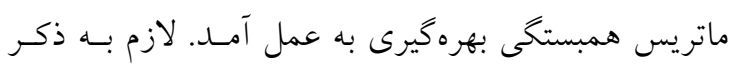

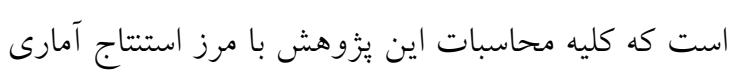

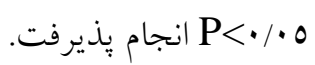

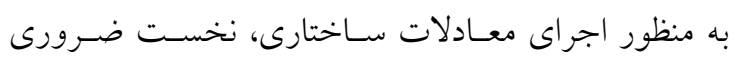

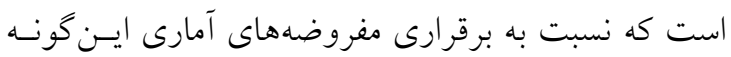

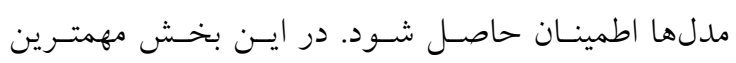

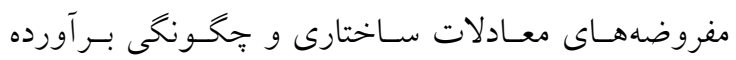

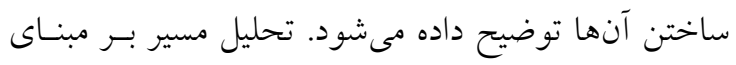

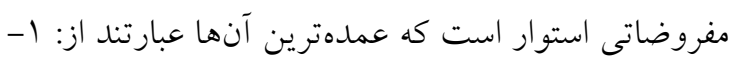

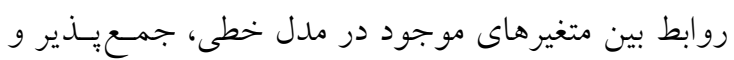

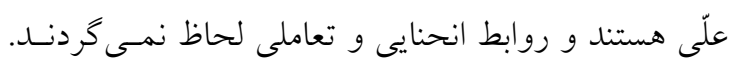

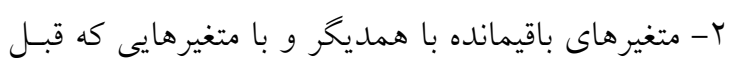

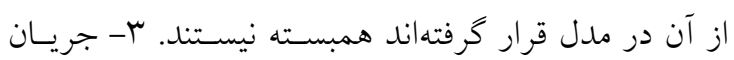
علّيت در دستخاه يك طرفه مىباشد و علّيت بين متغيرهـا

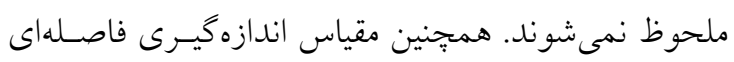

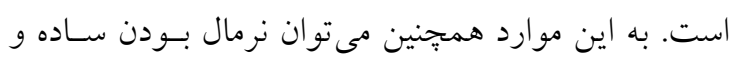

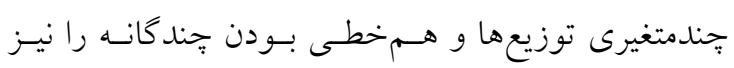

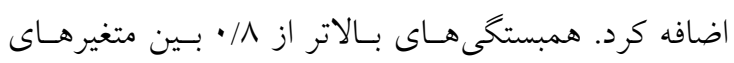

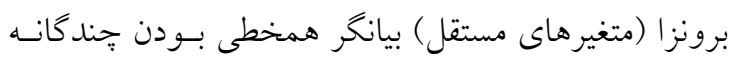
است. نتايج حاصل از محاسبه ضرايب همبستئكى (مرتبـه

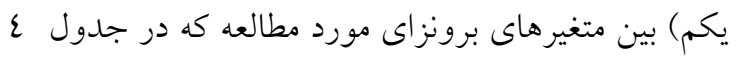

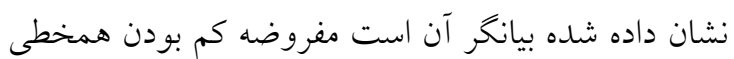

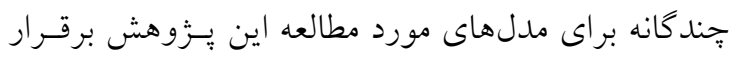

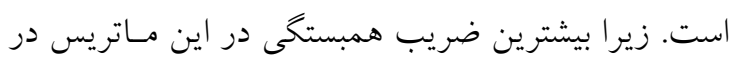

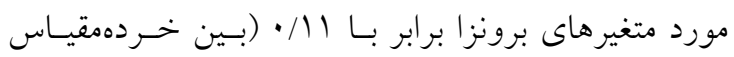

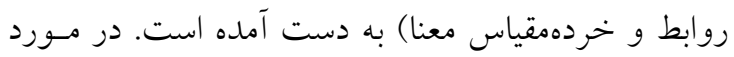

دست آوردند. يايايى اين زيرسشنامه در يزوهشى ديخر

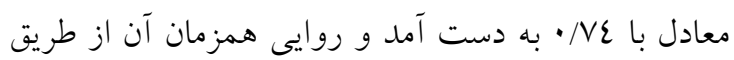

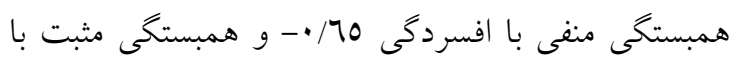

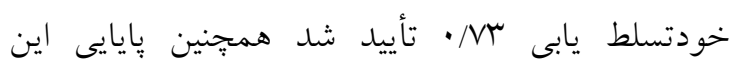

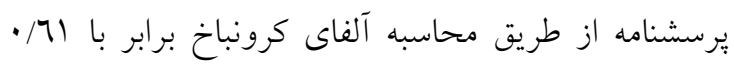

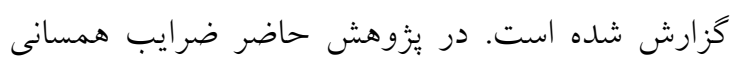

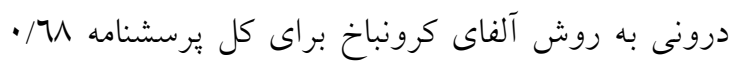
به دست آمد.

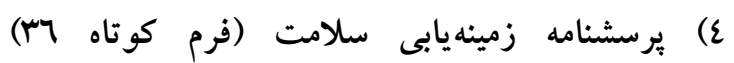
(36-Item Short-Form Health Survey) (SF-36)

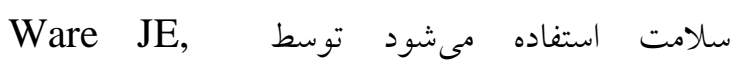
ساخته شد و داراى حس عبارت است و 1 Sherbourne قلمرو عملكرد جسمى، عملكرد اجتماعى، ايفاى نقش جسمى، ايفاى نقش هيجانى، سلامت روانى، سرزندكى، لمدي،

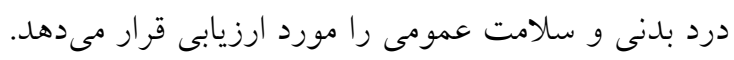

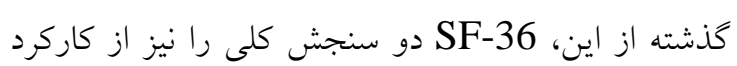

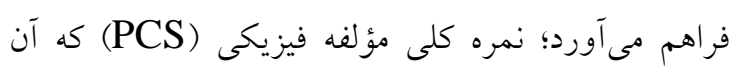

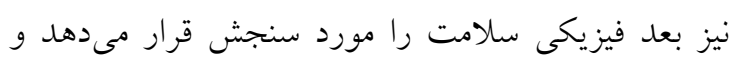

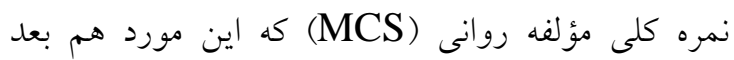

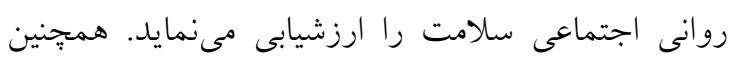

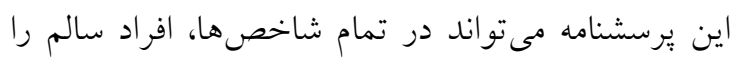

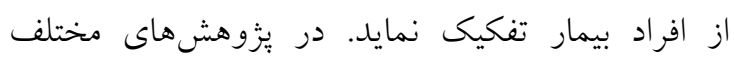
ويزگى هاى روانسنجى اين برسشنامه مورد تأييد قرار

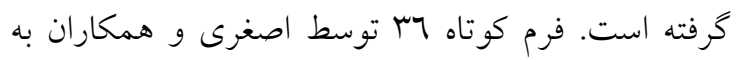

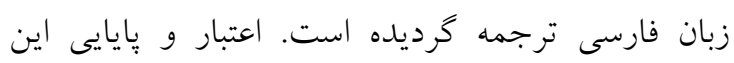

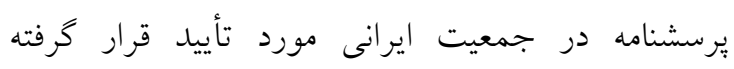
است (1). همجنين ضرايب همسانى درونى خرده مقياس

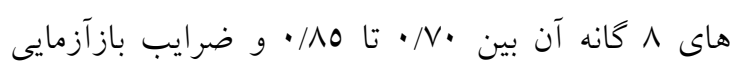

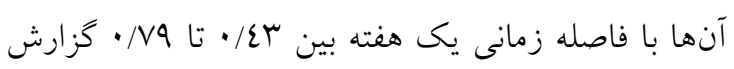

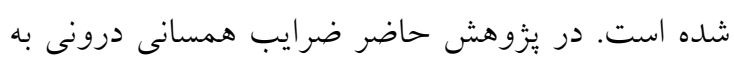

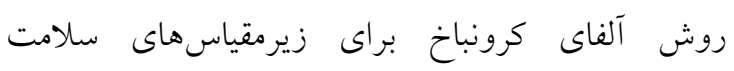

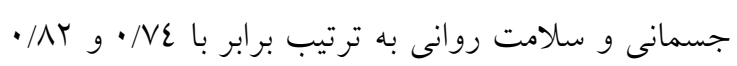
و براى كل مقياس V7/ • به دست آمداني به ترئب برابر 
مدل سلامت جسمى - روانى دانشجويان رشـته برسـتارى

$$
\text { ارائه مىشود (19). }
$$

\section{يافتهها}

با توجه به جدول شماره ا، تعداد كل آزمودنىها ...ب نفر

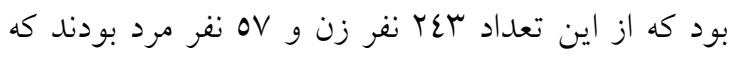
به ترتيب 11 درصد و 19 درصد از كل نمونهها را شامل نسل مىشوند. همجنين ميانگين سنى كل آزمودنى هاى مورد

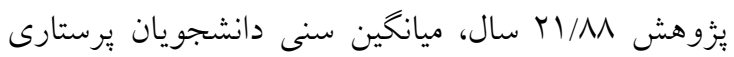

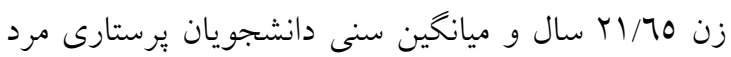

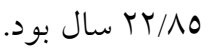

يكسانى بر اكندكى (همكونى واريانس) متغيرهـاى درونـزا

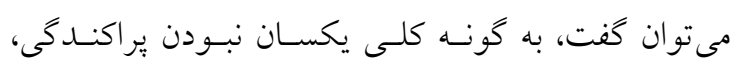

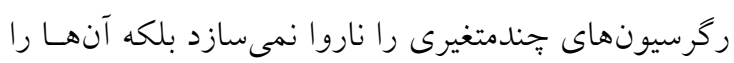

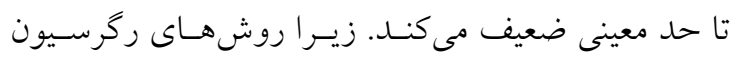

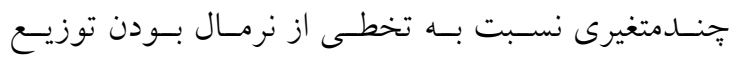

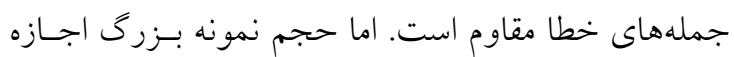

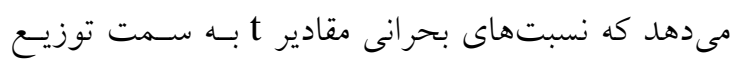

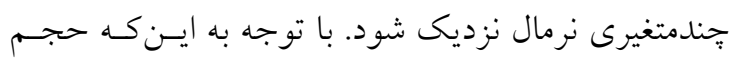
نمونه مطالعه حاضر نيز به اندازه كافى بزرى استـ (....

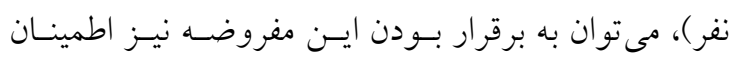

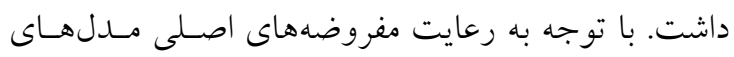
معادلات ساختارى، در ادامه فرايند تحليل دادهها و تبيـين

جدول شماره ا: توزيع فراوانى و ميانكين سنى آزمودنى هاى مورد يزوهش به تفكيك جنسيت

\begin{tabular}{|c|c|c|c|c|c|c|c|}
\hline \multicolumn{2}{|c|}{ دامنه نمرات سن } & انحراف استاندارد & ميانخين سنى & درصد & فر اوانى & شاخص آمارى & \\
\hline حداكثر & حداقل & نمرات سن & & فراو انى & & & جنسيت \\
\hline rT & 19 & $1 / \mathrm{VV}$ & $T 1 / 70$ & 1) & r & & دختر \\
\hline TV & 19 & $1 / 90$ & $T Y / \wedge O$ & 19 & ov & & ل جسر \\
\hline TV & 19 & $1 / \wedge 7$ & YI/AM & $1 \ldots$ & r.. & & كل \\
\hline
\end{tabular}

(اس/•)، با خردهمقياس روابط (•//•) و با خردهمقياس

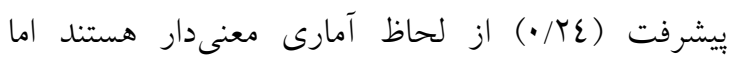

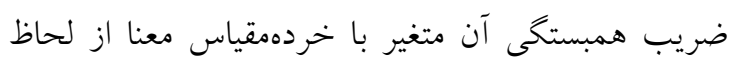
آمارى معنىدار نبود. بنابراين همبستخى و روابط دوتايى ميى بين برخى از متغيرهاى يزوهش معنى دار است و همين

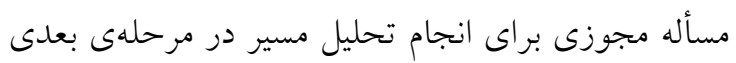
كرديل. همجنين خرده مقياس معنا، نه به صورت مستقيم و نه غيرمستقيم معنى دار نبوده و تغييرى در ميزان سلامت

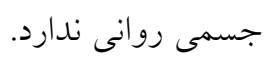

به منظور ارائه تصويرى روشن از وضعيت متغيرها و رابطهى بين آنها، در جدول شماره ا ميانخين، انحراف استاندارد و ضريب همبستخى بيرسون (مرتبه صفر ) آورده شده است. همانكونه كه جدول شماره Y نشان مىدهد ضرايب همبستخى سلامت جسمى - روانى با ساير متغيرهاى بزوهش به جز خردهمقياس معنا نسبتاً متوسط و رو معنى دار است. سلامت جسمى - روانى بيشترين همبستخى را با خوشبينى (اس/ •) و كمترين همبستخى را با خردممقياس معنا (///) دارد. همجنين ضرايب همبستخى متغير خوشبينى با خردهمقياس هيجانات مثبت 


\begin{tabular}{|c|c|c|c|c|c|c|c|c|}
\hline SD & $\mathbf{M}$ & 7 & 0 & $\varepsilon$ & $r$ & $r$ & 1 & متغيرها \\
\hline r/or & $r \cdot / N V$ & & & & & & 1 & |- هيجانات مثبت (شكوفايى) \\
\hline T/TO & $r 1 / 90$ & & & & & 1 & $\cdot / \cdot r$ & ז- روابط (شكوفايى) \\
\hline $1 / 99$ & $M T / T V$ & & & & 1 &.$/ 11$ & $\cdot / \cdot 1$ & ז- معنا (شكوفايى) \\
\hline $1 / N \varepsilon$ & $M 1 / 77$ & & & 1 & $\cdot /$ & $\cdot / \cdot \varepsilon$ & $\cdot / \cdot v$ & ع- يِيشرفت (شكوفايى]] \\
\hline T/ & $10 / v 9$ & & 1 & 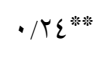 & $\cdot / 1$ & 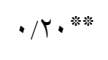 & $\cdot / \mu I^{* * * * *}$ & 0- خوشبينى \\
\hline $\mid \varepsilon / \varepsilon \wedge$ & $1.9 / \varepsilon V$ & 1 & $\cdot /\left.\right|^{* * * * *}$ & $\cdot / 17^{\text {*** }}$ & $\cdot /$ & $\cdot / \Upsilon 7^{*}$ & $\cdot / \Upsilon \nearrow^{*}$ & 7- سلامت جسمى - روانى \\
\hline
\end{tabular}

$* * \mathrm{P}<\cdot / \cdot 1 \quad * \mathrm{P}<\cdot / \cdot 0$

در مدل مطالعه حاضر بنابر يافتهاى تجربى و مبانى مسمى - روانى يرستاران در نظر كرفته شد. به منظور

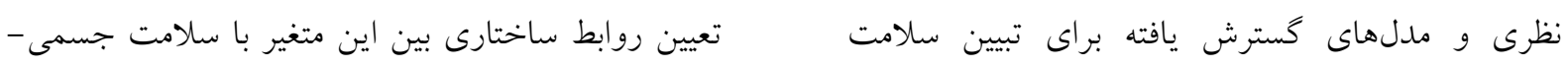

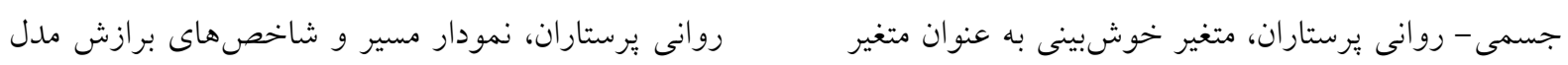

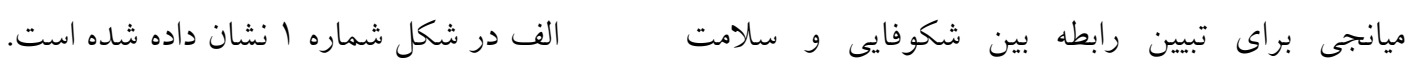

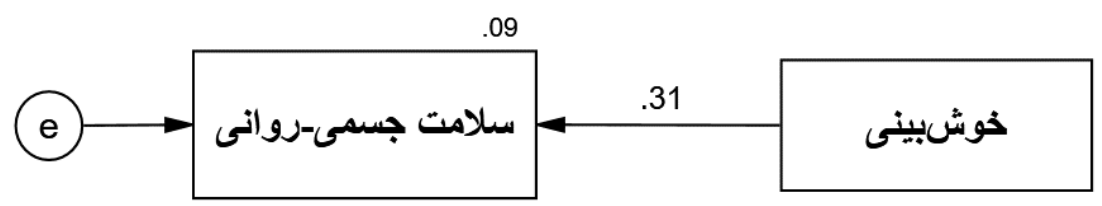

شكل شماره ا: نمودار مسير مدل الف براى تبيين سلامت جسمى - روانى يرستاران

مدلى مبتنى بر اين متغيرها با ميانجى گرى متغير

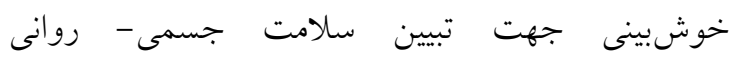
دانشجويان يرستارى مورد آزمون قرار كرفت كه نتيجه

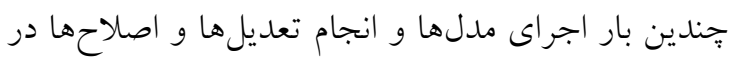

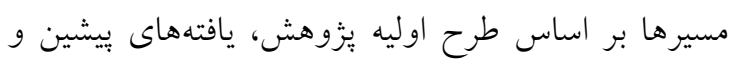

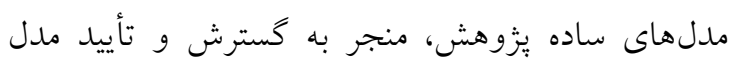
نهايى شد كه نمودار مسير آن در شكل شماد شماره ب نش نشان

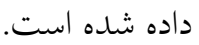

جنانكه در شكل شماره 1 و جدول شماره ب ديده مىشود ضريب مسير خوشبينى به سلامت جسمى

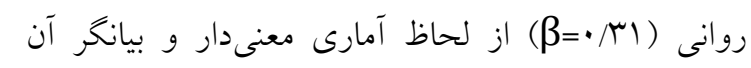
است كه مىتواند سلامت جسمى- روانى دانشجويان

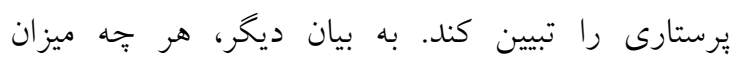

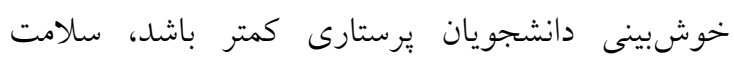

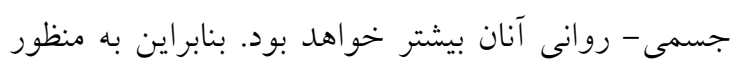
بررسى نقش ميانجى متغير خوشبينى در رابطه بين بين

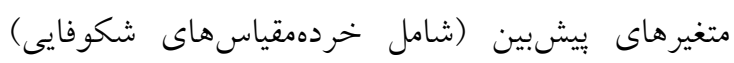

جدول شماره بّ: تخمين وزنهاى رتر سيونى مدل الف براى تبيين سلامت جسمى - روانى بر ستاران

\begin{tabular}{|c|c|c|c|c|}
\hline سطح معنى دارى & ن نسبت بحرانى & خطاى معيار & تخمين & 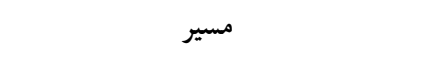 \\
\hline . $\cdots$ & $0 / 009$ & $\cdot / r \varepsilon r$ & $1 / 9 \cdot r$ & خوشبينى † سلامت جسمى-روانى \\
\hline
\end{tabular}




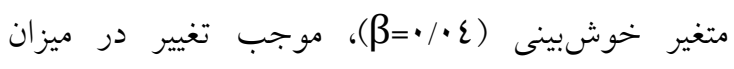
سلامت جسمى - روانى دانشجويان يرستارى مىشود.

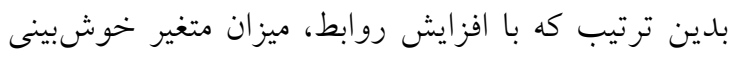

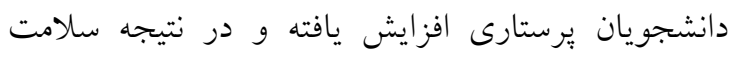

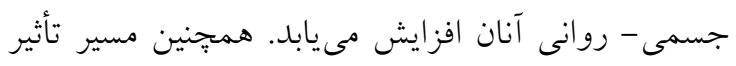

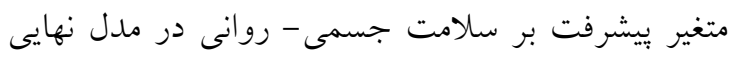

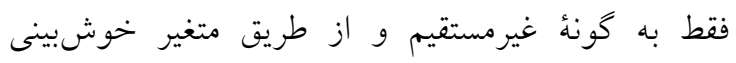

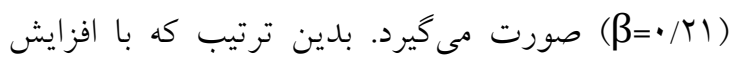

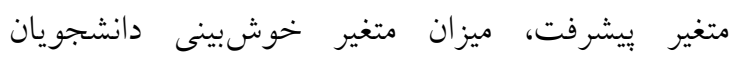
يرستارى افزايش يافته و در نتيجه سلامت جسمى - روانى ميرن

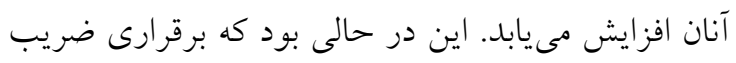
مستقيم براى متغير معنا به سلامت جسمى - روانى نه تنها

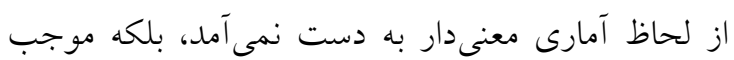

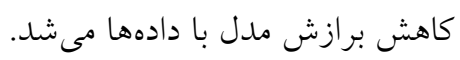

جنان كه در شكل شماره r ديده مىشود متغيرهاى برونزا

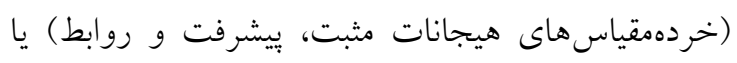
به صورت مستقيم و يا از طريق متغير ميانجى مىتوانند سلامت جسمى - روانى دانشجويان يرستارى را تبيين

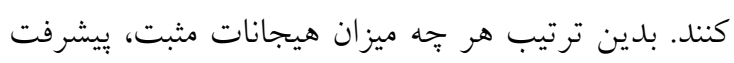
و روابط شكوفايى، بيشتر باشد، سلامت جسمى - روانى دانشجويان يرستارى نيز بيشتر خواهل بود. متغير هيجانات

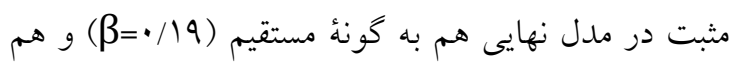

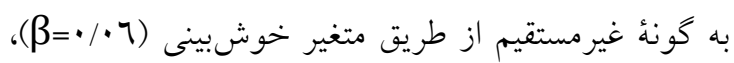
موجب تغيير در ميزان سلامت جسمى - روانى دانشجويان يرستارى مىشود. بدين ترتيب كه با افزايش هيجانات

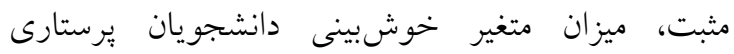
افزايش يافته و در نتيجه سلامت جسمى- روانى آنان افزايش مىيابد. متغير روابط در مدل نهايى هم به كونه

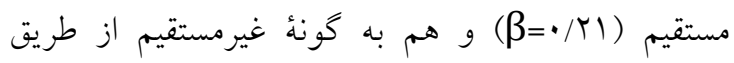

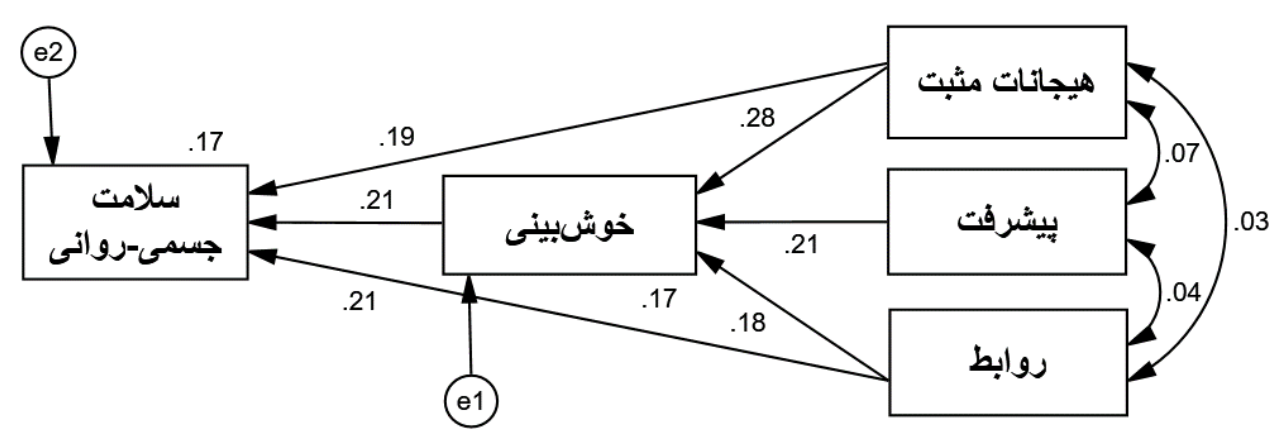

شكل شماره r: مدل مسير اثر شكوفايى بر سلامت جسمى - روانى دانشجويان برستارى با ميانجى ترى خوشبينى (مدل نهايى)

جنانكه در جدول شماره ع ديده مىشود همهى ضرايب بيانگر آن است كه متغيرهاى درونزا مىتوانند سلامت

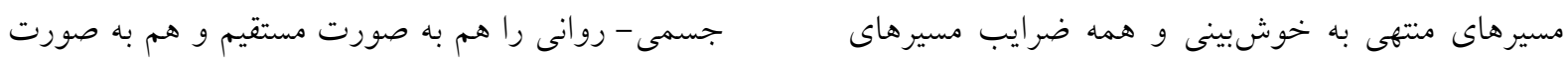

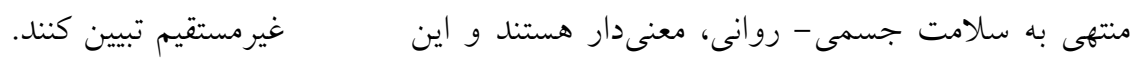

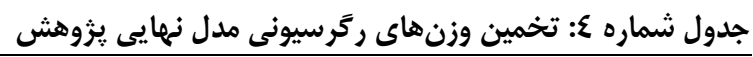

\begin{tabular}{|c|c|c|c|c|}
\hline سطح معنى دارى & ن نسبت بحرانى & خطاى معيار & تخمين & مسير \\
\hline$\cdot / \cdots 0$ & $0 / r v q$ & .1 .40 &.$/ 1 M$ & هيجانات مثب ك خوشبينى \\
\hline$\cdot \cdots \cdot$ & $r / 917$ & $\cdot / \cdot v 1$ & $\cdot / T V 7$ & ييشرفت ك خوش بينى \\
\hline$\cdot / \cdots \circ$ & $r / 270$ &.$/ .0 \varepsilon$ & $\cdot / 1 \wedge 9$ & روابط † خوشبينى \\
\hline$\cdot / \cdots \circ$ & $\Gamma / 277$ & $\cdot \pi r \Lambda$ & ./va. & هيجانات مثبت † سلامت جسمى - روانى \\
\hline$\cdot / \cdots 0$ & r/ANV & $\cdot \pi \varepsilon 7$ & $1 / \pi \varepsilon 7$ & روابط ٪ سلامت جسمى- روانى \\
\hline$\cdot / \cdots \circ$ & $r / 7 r /$ & . ror & $1 / T V V$ & خوشبينى † سلامت جسمى - روانى \\
\hline
\end{tabular}




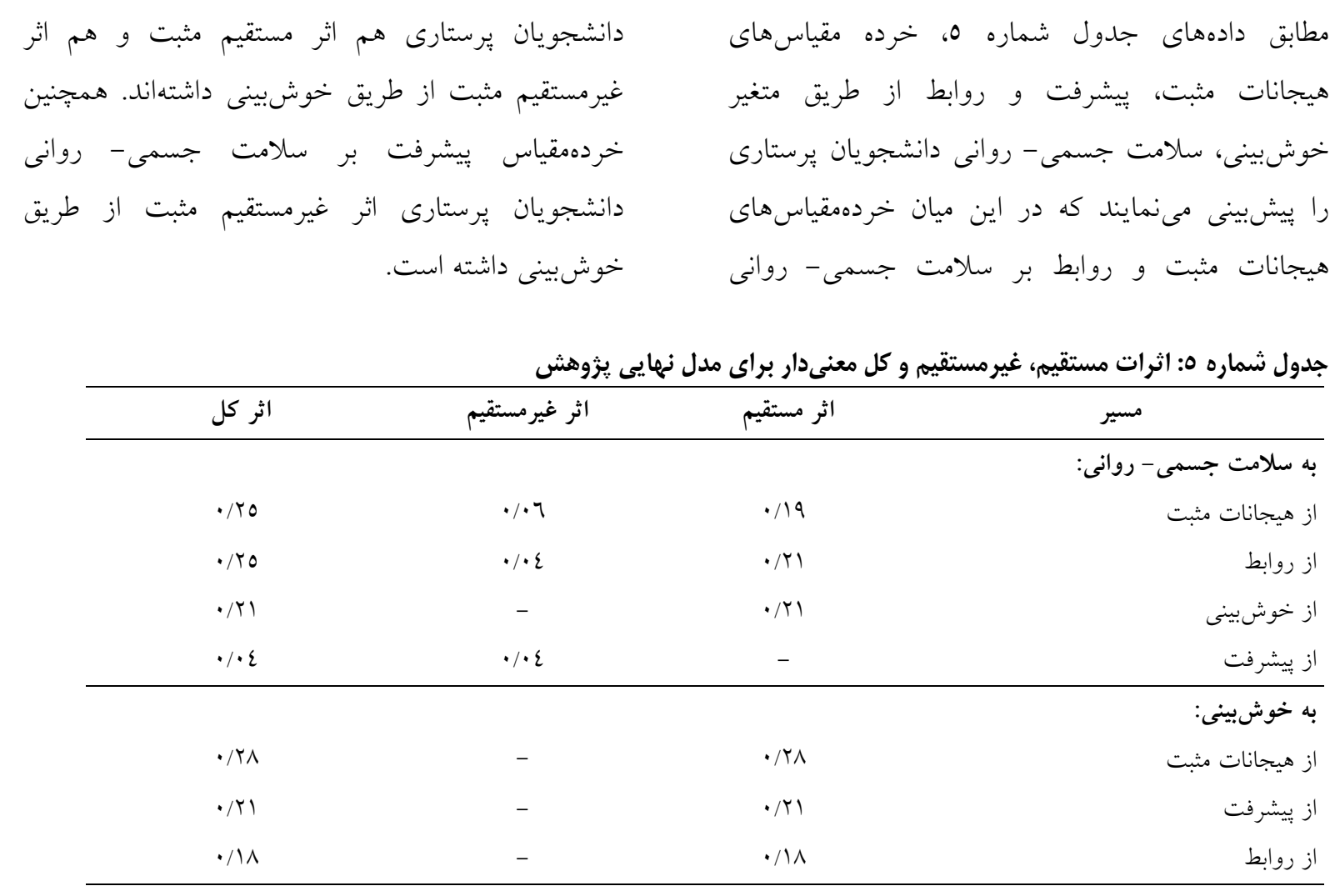

مىتوان كفت دادها مدل نظرى يزوهش را تا حد زيادى

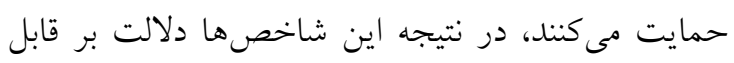

قبول بودن مدل دارند.
مطابق دادهاى جدول شماره 1، شاخصهاى ارزيابى كليت مدل مسير در مجموع بيانخر اين است كه برازش

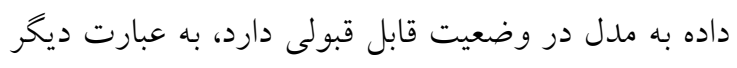

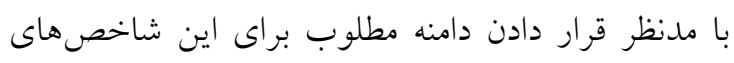

\begin{tabular}{|c|c|c|c|c|c|c|c|c|}
\hline \multirow{2}{*}{\multicolumn{2}{|c|}{ HOELTRE }} & \multirow{3}{*}{ CFI } & \multirow{3}{*}{ NFI } & \multirow{3}{*}{ RMSEA } & \multirow{3}{*}{ AGFI } & \multirow{3}{*}{ GFI } & \multirow{3}{*}{ CMIN/df } & \multirow{3}{*}{ "شاخص آمارى" } \\
\hline & & & & & & & & \\
\hline.$/ \cdot 1$ & .1 .0 & & & & & & & \\
\hline$\geq r \cdot$. & $\geq r .$. & $\geq \cdot 19$ & $\geq \cdot / 9$ & $\leq \cdot / \cdot \wedge$ & $\geq \cdot / 9$ & $\geq \cdot / 9$ & $\leq r$ & دامنه يذيرش \\
\hline$v \pi \varepsilon$ & ETO & $\cdot / 9 \wedge \varepsilon$ &.$/ 9 \mathrm{VV}$ & $\cdot / \cdot \vee 7$ & $\cdot / 9 \varepsilon 7$ &.$/ 997$ & $Y / N \cdot 7$ & مقدار محاسبه شده \\
\hline
\end{tabular}

خوشبينى، سلامت جسمى - روانى دانشجويان يرستارى

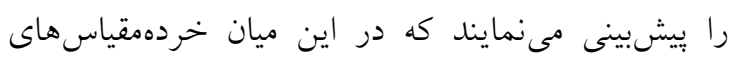

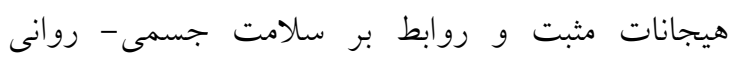

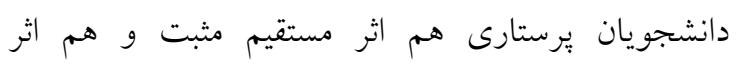

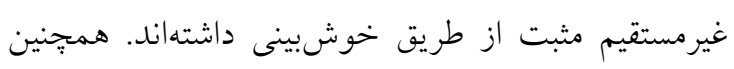

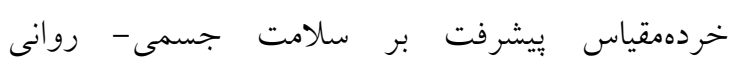

\section{بحث و نتيجه تيرى}

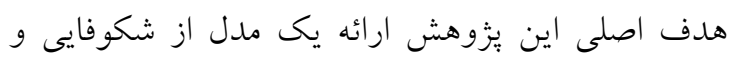
خوشبينى براى كمك به فهم بهتر سلامت جسمى -

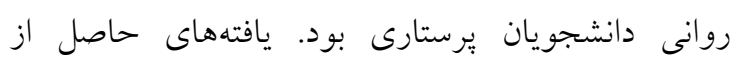

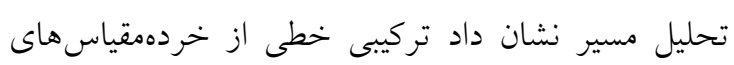
هيجانات مثبت، يبشرفت و روابط از طريق متغير 
مقايسه با افراد بدبين، استرس، اضطراب و بريشانى روانى

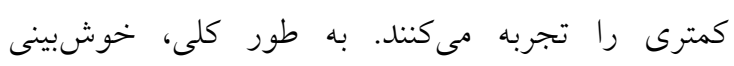

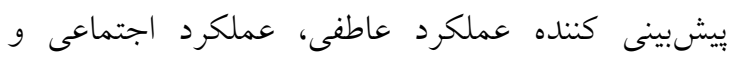
كيفيت زندگى بهتر است و بنابراين بنا به دلايل مذكور

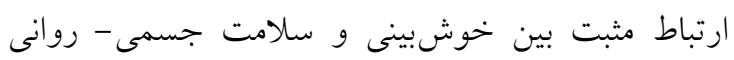
قابل توجيه است. نتايج ديخر يزوهش نشان داد، مدل رولئ روابط ساختارى

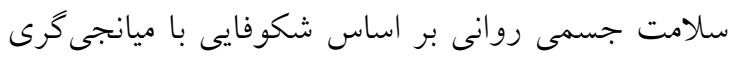
خوشبينى و عاطفه مثبت در دانشجويان، مدلى روا است.

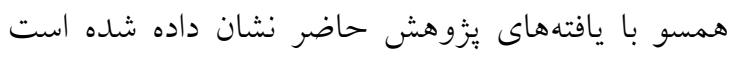

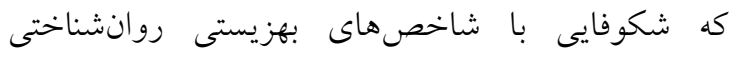

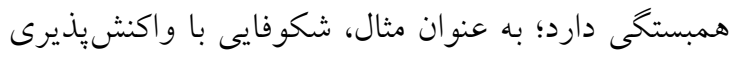

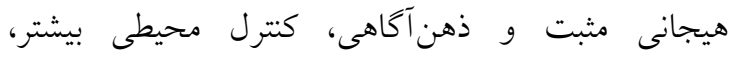

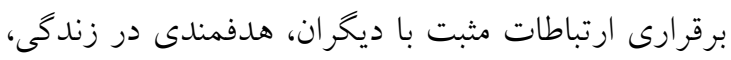

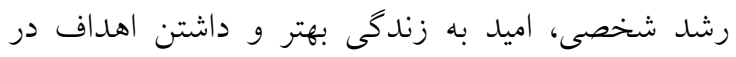

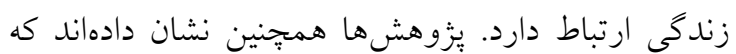

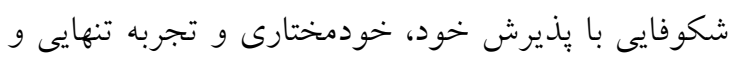

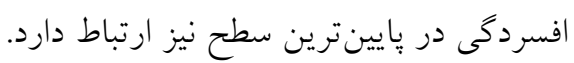

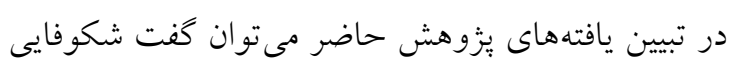

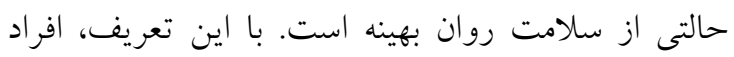

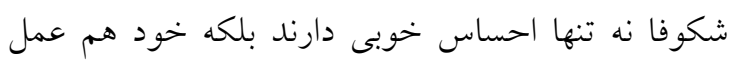
مى كنند. آنها به طور منظم هيجانهاى خوبى تجربه

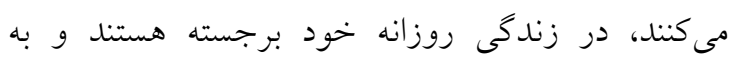

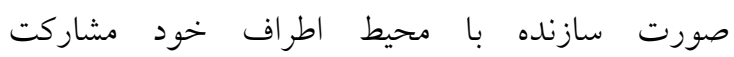

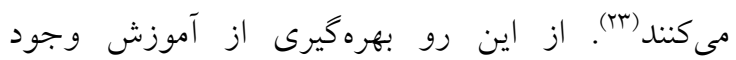

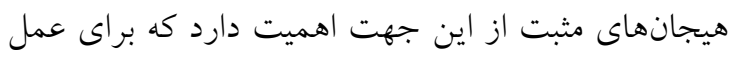
كردن، احتمالات و امكانات بيشترى را در اختيار خواهند داشت و خزانه تفكر و عمل را در لحظه كسترش مىدهند، و در كذر زمان منابع تقويتى و شخصى ونى كوناكون ساخته و يرداخته مىشود و در همين حين يبيوندهاى اجتماعى مختلف توسعه يافته و در نتيجه روابط

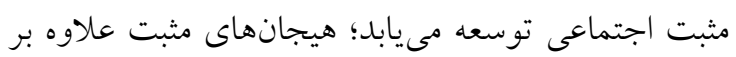
توسعه خزانه تفكر و عمل و ساختن منابع شخصى يايدار ظرفيت خنثى كردن هيجانهاى منفى طولانى را هم دارند.
دانشجويان يرستارى اثر غيرمستقيم مثبت از طريق

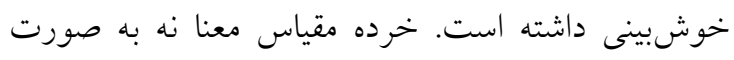
مستقيم نه به صورت غير مستقيم معنى دار نبوده و تغييرى بر سلامت جسمى روانى ندارد.

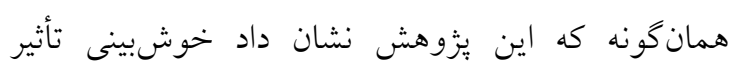
مستقيم بر سلامت جسمى - روانى دانشجويان دارد.

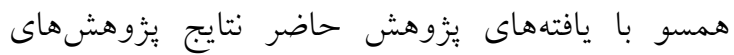
Posadzki

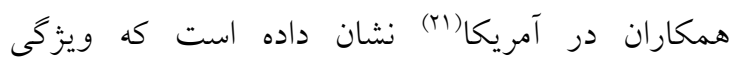
شخصيتى خوشبينى در مقابله با فشارهاى زندكى و غلبه بر ناملايمات روانى- اجتماعى در اقدام به رفتارهاى مرتبط با سلامت، اصلاح سبك زندكى و در در نهايت كاهش بروز بيمارىهاى جسمانى و روانى تأثير مهمى

در تبيين رابطه بين خوشبينى و سلامت جسمى - روانى

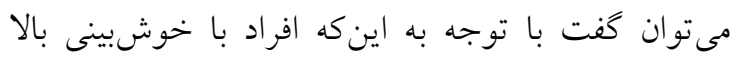

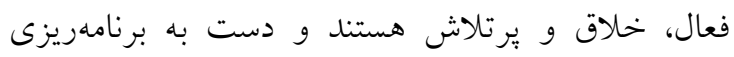

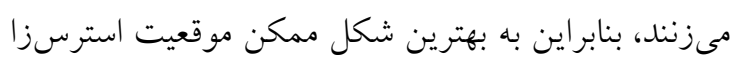

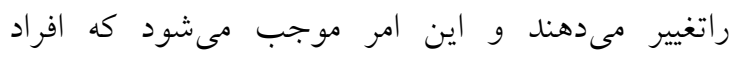

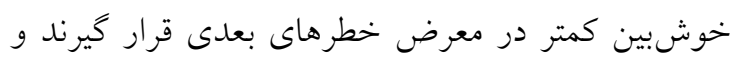
فشار ناشى از حوادث استرسزا نيز براى آنها كمتر باشد.

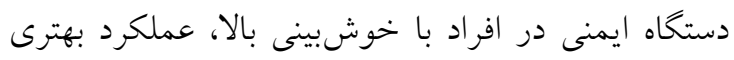

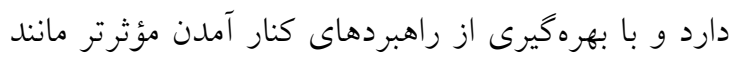

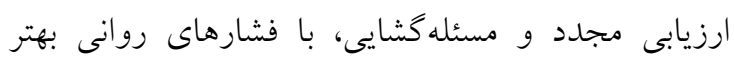

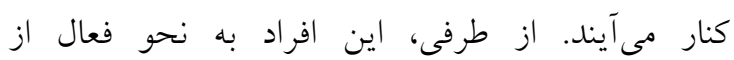

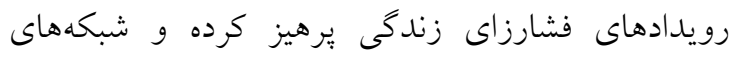
حمايت اجتماعى بهترى را يُيرامون خود مىسازند،

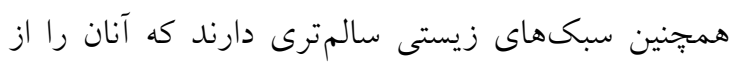
ابتلاى به بيمارى حفظ مىكند و اخر هم بيمار شوند به

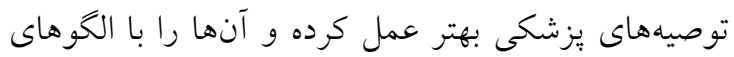
رفتارى دنبال مى كنند كه بهبودى را سرعت مىبخشد.

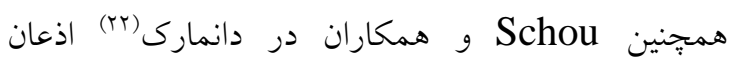
مىدارند افراد خوشبين به دليل تلاش براى حفظ روابط همان خود با ديخران و دريافت حمايت اجتماعى بيشتر در 
كه به افراد كمى مى كند تا با حوادث پِراسترس زندكى كنى

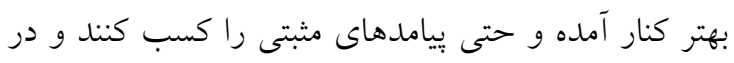

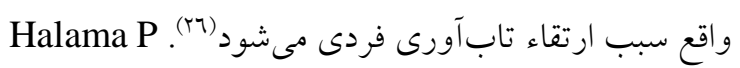
Dedova در ييش بينى سلامت جسمى - روانى است. CarverCS Scheier MF, Segerstrom خوشبينى قابليت دفاعى بدن را جهت مقابله با بيمارىها

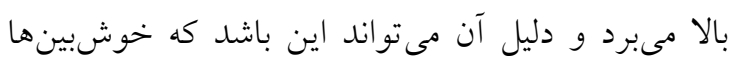
پايينترين سطح تنش را در يكى اجتماع دارند. افراد

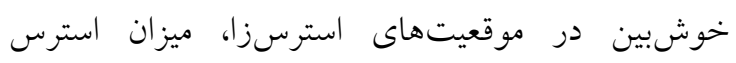
كمترى را ادراك كرده و گزارش مى كنند، هم:جنين مطالعه Levkovich I, Cohen خوشبينى و سطوح افسردگى در بيماران كزارش دادهاند. بيماران داراى سطح بايين خوش بينى و سطح بالاى بلدبينى

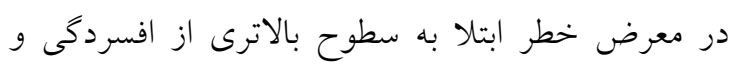

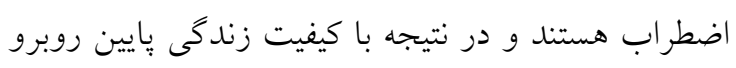

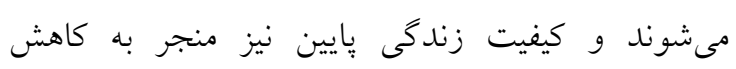
سلامت جسمى - روانى مىشود. Evangelos

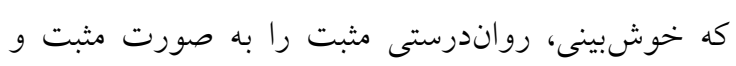

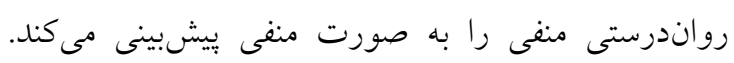

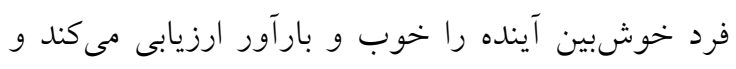

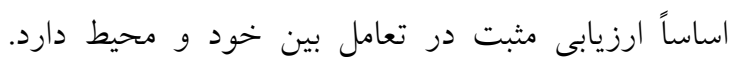

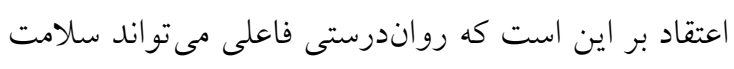
جسمى و روانى را بهبود بخشد. Segerstrom در كانادا

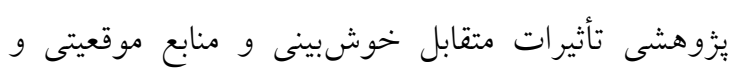

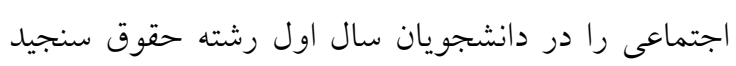

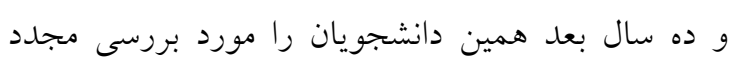

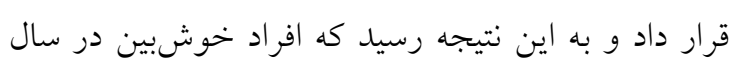

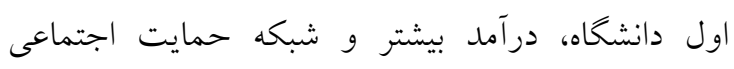

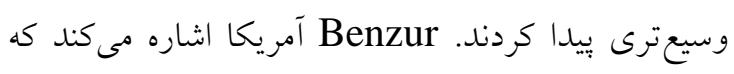
خوشبينى در نوجوانان با عاطفه منفى رابطهى منفى و با باديا

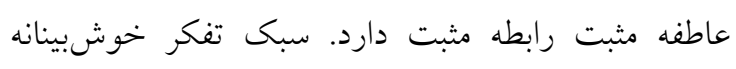
نوجوانان را در برابر خطرات سلامتى محافظت مى كند و وبند
براى مثال ما در تجارب منفى نيز سعى مىكنيم معنايى

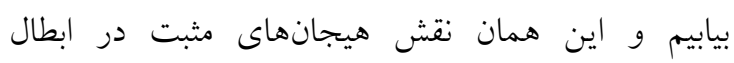

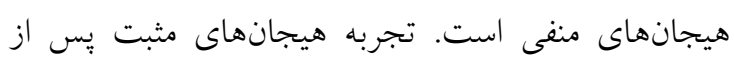

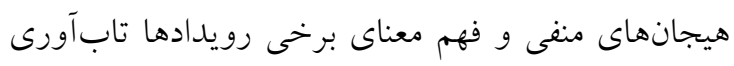

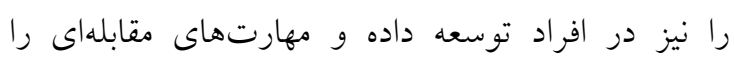

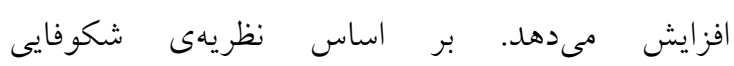

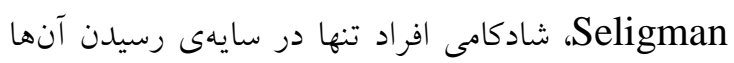

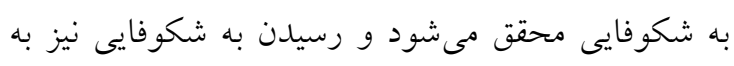

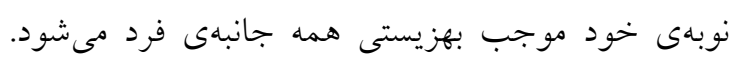

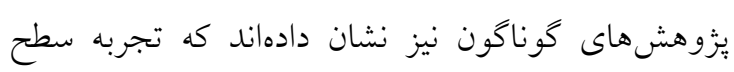

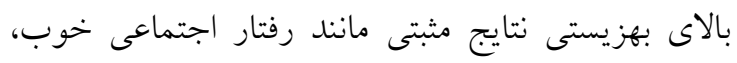

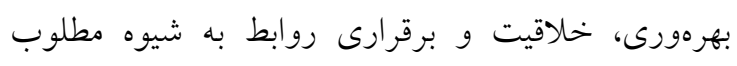
خواهد داشت. Amabile TM, Barsade در آمريكا به اين نتيجه دست يافتند كه تجربه هيجانهاى مثبت،

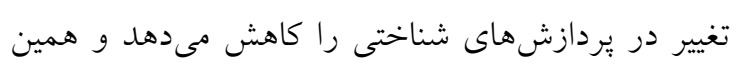

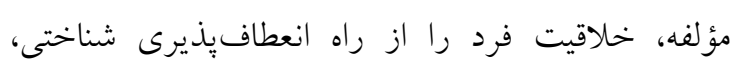

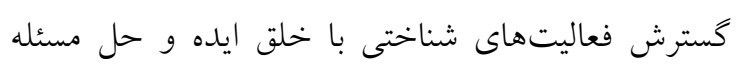

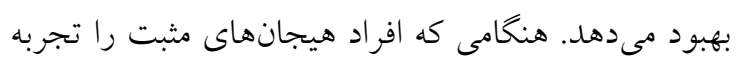

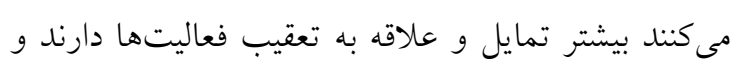

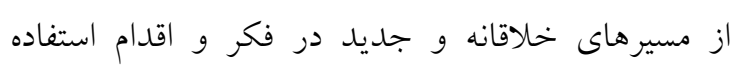

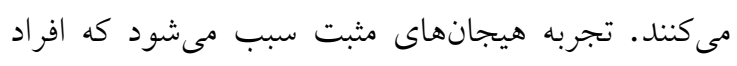

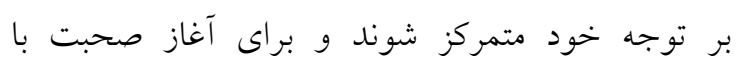

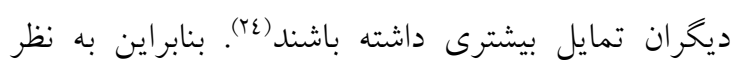

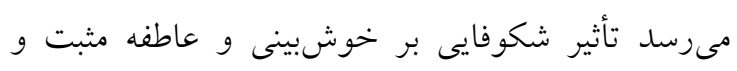

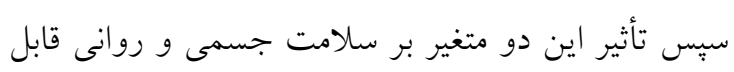

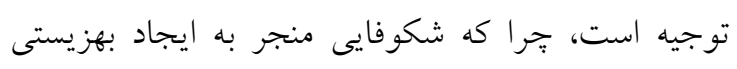

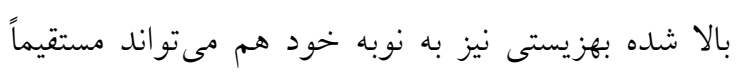

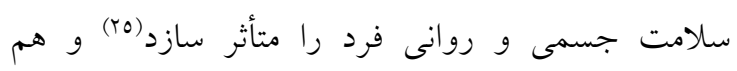

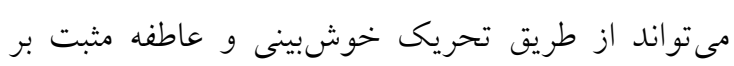
سلامت روانى و جسمى فرد تأثير كذارد. در تبيين نقش ميانجى گرى خوش فيبنى در رابطه بين فين

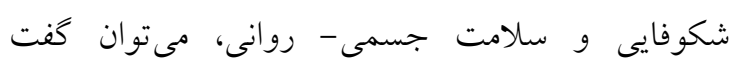

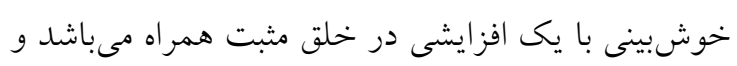
همجنين منجر به ارتقاء مكانيزم سازكارى فعال مى دشود 
جهت افزايش خوشبينى و استفاده از فنون روانشناسى

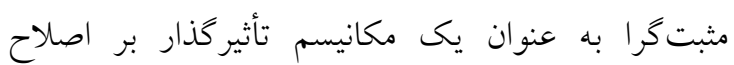

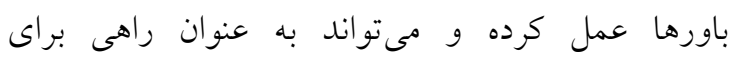

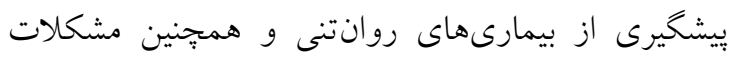
روانى دانشجويان رشته يرستارى در نظر كرفته شود.

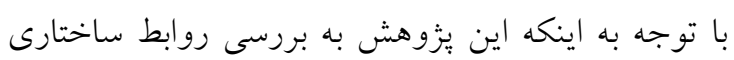

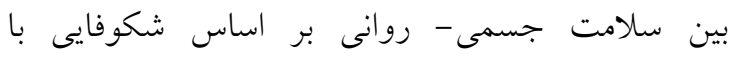

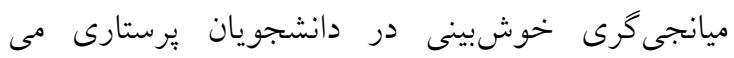

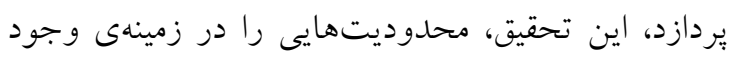

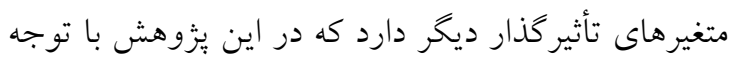

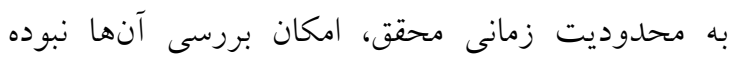

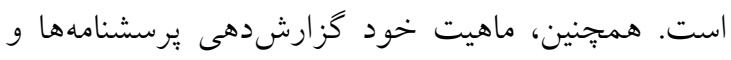
استفاده نكردن از مصاحبههاى روانشناختى ساختاريافته از جمله محدوديتهاى ديخر اين مطالعه بود.

تضاد منافع: هيج گونه تضاد منافعى در اين يُزوهش وجود ندارد

\section{تقدير و تشكر}

اين مقاله بركرفته شده از يكى باياننامه دكترى دانشعاه

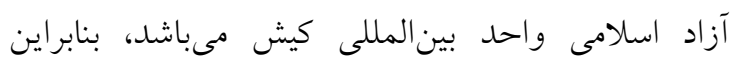

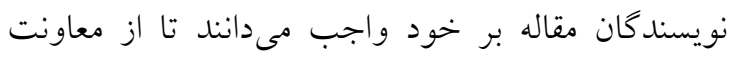

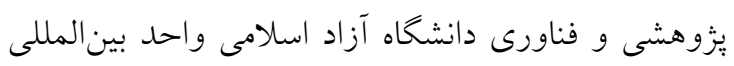

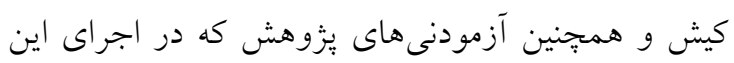
تحقيق ما را همراهى كردند، تشكر و قدردانى نمايند.

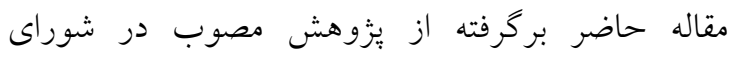

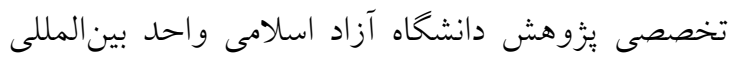

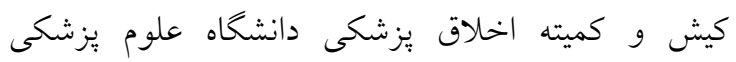

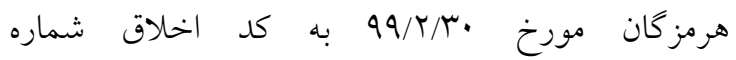
IR.HUMS.REC.1399.116 مى باشد.
در برابر علائم افسردگى نيز مؤثر است. ترويج خوشبينى

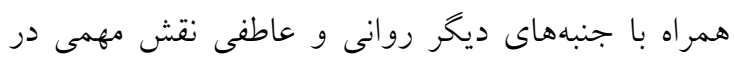

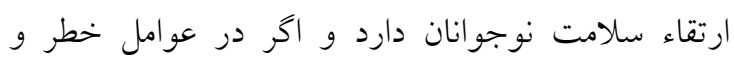
عوامل حمايتى و زمينههاى اجتماعى نوجوانان مداخله كنيم، احتمال دارد كه سلامت آنها افزايش يابد زئدي

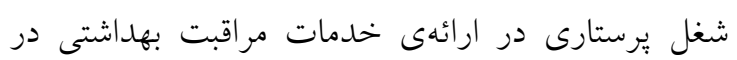
هملى كشورها داراى نقش محورى بوده و بنابراين سلامت جسمى - روانى يرستاران و همجينين بهبود

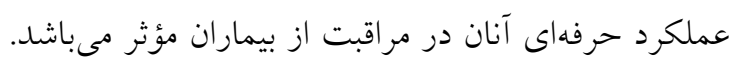

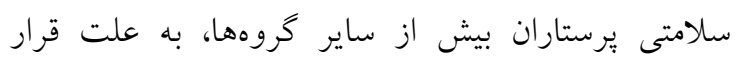

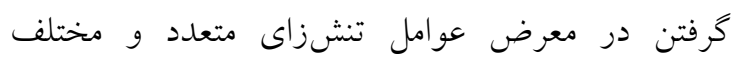

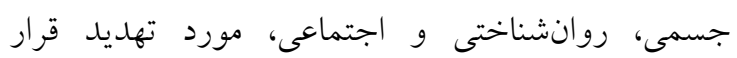

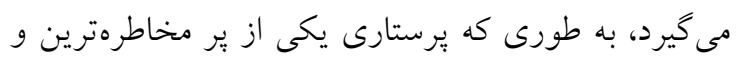

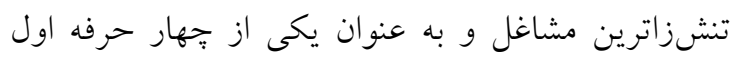

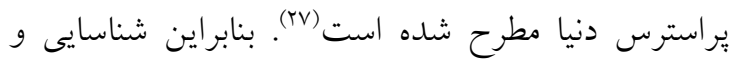
تعيين عوامل مرتبط با سلامت جسمى - روانى يرستاران

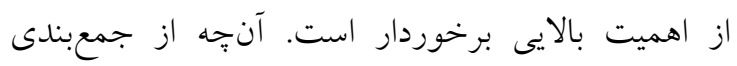

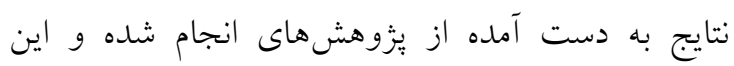

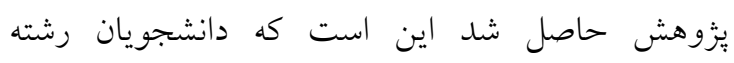

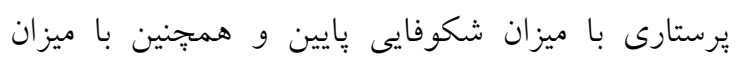

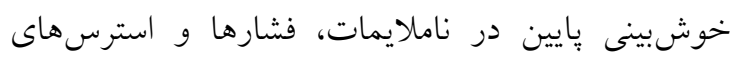

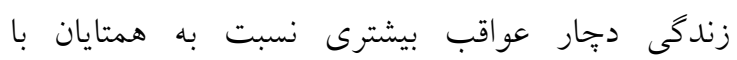

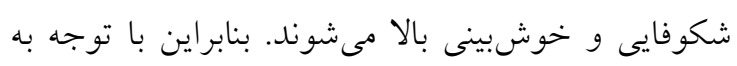

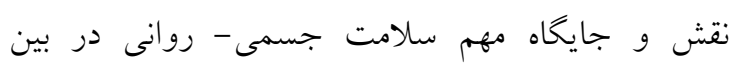
دانشجويان و به ويزه دانشجويان رشته برستارى كه شغل

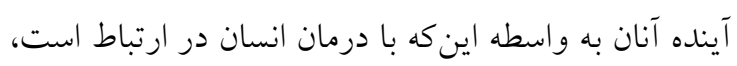
به نظر مىرسد محيطهاى آموزش برستارى بايد به دنبال بهان

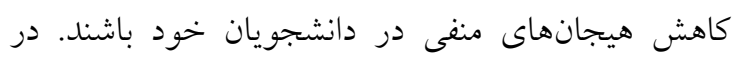

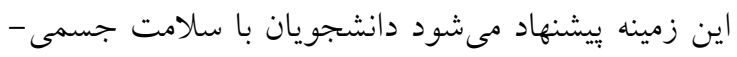

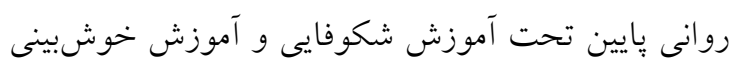

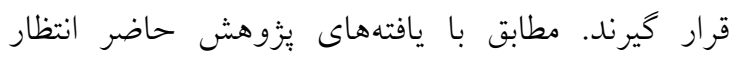

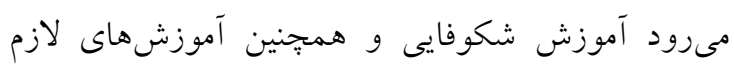




\section{References}

1. Pisanti R, van der Doef M, Maes S, Lazzari D, Bertini M. Job characteristics, organizational conditions, and distress/well-being among Italian and Dutch nurses: a cross-national comparison. Int J Nurs Stud. 2011;48(7):829-37.

2. Baghianimoghadam MH, Dehghanpour M, Shahbazi H, Kahdouee J, Dastgerdi G, Falahzadeh H. A survey relation between optimism and general health in university students in Yazd Iran. Tolooebehdasht. 2013;12(2):89-101. [Persian]

3. Salimi H, Haji Alizadeh K, Sedaghat Ghotbabadi S, Nikrouy F. Evaluating the mediator role of marital adjustment in relation to prediction of physical and mental health among primary school married teachers. Iranian Journal of Health Education and Health Promotion. 2017;4(4):289-99. [Persian]

4. World health organization. WHO definition of Health. Available at: http://www.who.int/about/definition/en/print.html. [Cited 2015 Nov 15].

5. Seligman ME. Authentic happiness: Using the new positive psychology to realize your potential for lasting fulfillment. Simon and Schuster; 2004.

6. Seligman ME. Flourish: A visionary new understanding of happiness and well-being. Simon and Schuster; 2012 Feb 7.

7. Michalec C, Keyes CLM, Nalkur S. Flourishing. Chichester, England: Wiley-Blackwell. 2009.

8. Catalino LI, Fredrickson BL. A Tuesday in the life of a flourisher: The role of positive emotional reactivity in optimal mental health. Emotion. 2011;11(4):938-50.

9. Telef BB, Ölçeği Pİ. The Validity and Reliability Study of The Psychological Well-Being or Flourishing Scale. $11^{\text {th }}$ ed. National Congress of Counseling and Guidance, Izmir, Turkey. 2011.

10. Faulk KE, Gloria CT, Steinhardt MA. Coping profiles characterize individual flourishing, languishing, and depression. Anxiety, Stress \& Coping. 2013;26(4):378-90.

11. Scheier MF, Carver CS. Optimism, pessimism, and self-regulation. In E. C. Chang ed., Optimism \& pessimism: Implications for theory, research, and practice p:31-51. American Psychological Association. 2001.

12. Cheng ST, Chan AC. Measuring psychological well-being in the Chinese. Person Indiv Differ. 2005;38(6):1307-16.

13. Jobin J, Wrosch C, Scheier MF. Associations between dispositional optimism and diurnal cortisol in a community sample: when stress is perceived as higher than normal. Health psychology. 2014;33(4):382-91.

14. Lavasani M, Ejei J, Mohammadi F. The relationship between meaning of life and optimism with subjective well-being. Journal of Psychology. 2013;17(1):3-17. [Persian]

15. Zenger M, Brix C, Borowski J, Stolzenburg JU, Hinz A. The impact of optimism on anxiety, depression and quality of life in urogenital cancer patients. Psycho-Oncology. 2010;19(8):879-86.

16. Darvishpoor Kakhki A, Ebrahim H, Alavi Majd H. Health status of nurses of hospitals dependent to Shahroud Medical University. Iran journal of Nursing. 2009;22(60):19-27. [Persian]

17. Salimi H, Haji Alizadeh K, Sedaghat Ghotbabadi S, Nikrouy F. Evaluating the mediator role of marital adjustment in relation to prediction of physical and mental health among primary school married teachers. Iranian Journal of Health Education and Health Promotion. 2017;4(4):289-99. [Persian]

18. Ware Jr JE, Sherbourne CD. The MOS 36-item short-form health survey (SF-36): I. Conceptual framework and item selection. Medical care. 1992:473-83.

19. Seligman ME. Flourish: A visionary new understanding of happiness and well-being [Measurement instrument] New York. 2011.

20. Posadzki P, Stockl A, Musonda P, Tsouroufli M. A mixed-method approach to sense of coherence, health behaviors, self-efficacy and optimism: Towards the operationalization of positive health attitudes. Scand J Psychol. 2010;51(3):246-52.

21. Roberts ME, Gibbons FX, Gerrard M, Alert MD. Optimism and adolescent perception of skin cancer risk. Health Psychol. 2011;30(6):810-3.

22. Schou I, Ekeberg Ø, Sandvik L, Hjermstad MJ, Ruland CM. Multiple predictors of health-related quality of life in early stage breast cancer. Data from a year follow-up study compared with the general population. Qual life Res. 2005;14(8):1813-23. 
23. Keyes CL. Promoting and protecting mental health as flourishing: a complementary strategy for improving national mental health. Am psycholog. 2007;62(2):95-108.

24. Amabile TM, Barsade SG, Mueller JS, Staw BM. Affect and Creativity at Work. Admin Sci Quart. 2005;50(3):367-403.

25. Wood JV, Saltzberg JA, Neale JM, Stone AA, Rachmiel TB. Self-focused attention, coping responses, and distressed mood in everyday life. J Personal Soc Psychol. 1990;58(6):1027-36.

26. Huppert FA, So TT. Flourishing across Europe: Application of a new conceptual framework for defining well-being. Soc Indicat Res. 2013;110(3):837-61.

27. Pisanti R, van der Doef M, Maes S, Lazzari D, Bertini M. Job characteristics, organizational conditions, and distress/well-being among Italian and Dutch nurses: a cross-national comparison. Int J Nurs Stud. 2011;48(7):829-37. 